\title{
Heads of State Immunities, International Crimes and President Bashir's Visit to South Africa
}

\author{
Guénaël Mettraux, ${ }^{a}$ John Dugard ${ }^{b}$ and Max du Plessis ${ }^{c}$ \\ aProfessor of International Criminal Procedure, University of Amsterdam, \\ Amsterdam, The Netherlands \\ bEmeritus Professor of Law, Universities of the Witwatersrand, South Africa \\ and Leiden, The Netherlands \\ 'Barrister, South Africa, Senior Counsel; Associate Member, Doughty Street \\ Chambers and Associate Fellow, Chatham House, London, UK
}

\begin{abstract}
The relationship between international crimes and sovereign immunities has bedevilled judicial practice and legal scholarship and created an apparently irreconcilable tension between the two notions. Part of the difficulty in addressing this tension derives from the approach to resolving it. This paper proposes a novel approach, viewing the relationship specifically from the perspective of international criminal law and looking at the three core functions of immunities in that context. The authors

* G. Mettraux: Judge of the Kosovo Specialist Chambers; Counsel before international criminal tribunals; J. Dugard: Judge ad hoc, International Court of Justice; former member, International Law Commission; Senior Counsel, South Africa; M. du Plessis: Honorary Research Fellow, University of KwaZulu-Natal, Durban and Senior Research Fellow, Institute for Security Studies, Pretoria, South Africa. On 27 October 2016, Dr. Mettraux and Professor Dugard were granted leave by the Constitutional Court to appear as amicus curiae in the Minister of Justice and Constitutional Development \& Ors v. Southern African Litigation Centre (Case No. СCT 75/16) (Bashir case) and filed an amicus brief in these proceedings regarding the question of the relationship between immunities and international crimes. Following the withdrawal of the Government's application for leave to appeal to the Constitutional Court, proceedings were formally terminated as a result of which their amicus curiae brief was not considered by the Court. Mr. Du Plessis acted as counsel for the Southern Africa Litigation Centre in the litigation before the South African courts relating to Bashir's arrest in South Africa. The authors are grateful to Sarah Bafadhel and Lina Baddour for their precious comments and suggestions and to Bettina Ambach's Wayamo for allowing us to benefit from the views and opinions of a group of brilliant scholars.
\end{abstract}

(C) G. MEtTraUX ET AL., 2018 | DOI 10.1163/15718123-01804005

This is an open access article distributed under the terms of the prevailing CC-BY-NC license at the time of publication. 
conclude that customary international law excludes immunities as defence or bar to jurisdiction for core international crimes regardless of the nature of the jurisdiction concerned, the position of the accused, or the capacity in which the accused acted. When interpreted within that framework, the Icc Statute provides for clear limitations to the role of immunities in ICC proceedings and avoids the pitfalls that have thus far marred the ICc's approach to the law of immunities.

\section{Keywords}

immunities - heads of state - international crimes - International Criminal Court (ICC) - Bashir - jurisdiction - defence - judicial cooperation

\section{1 \\ Factual Background - President Bashir's Visit to South Africa ${ }^{1}$}

On 13 June 2015, South Africa was reminded by the International Criminal Court (ICC) of its 'obligation under the Rome Statute' to immediately arrest and surrender the sitting President of Sudan, Omar Al-Bashir (Bashir), during a visit to South Africa for an African Union (AU) Summit. ${ }^{2}$ President Bashir stands accused by the Court of involvement in the commission of various war crimes, crimes against humanity and acts of genocide. ${ }^{3}$ In issuing its decision,

1 A fuller version of the relevant procedural background has been laid out in a variety of publications. See in particular M. Ventura, 'Escape from Johannesburg? Sudanese President Al-Bashir Visits South Africa, and the Implicit Removal of Head of State Immunity by the UN Security Council in light of Al-Jedda', 13(5) JICJ (2015) 995-1025; M. du Plessis, 'The Omar Al-Bashir Case: Exploring Efforts to Resolve the Tension between the African Union and the International Criminal Court', in T. Maluwa, M. du Plessis, and D. Tladi (eds.), The Pursuit of a Brave New World in International Law: Essays in Honour of John Dugard (Brill-Nijhoff, Leiden, 2017), pp. 431-467.

2 Prosecutor v. Omar Hassan Ahmad Al Bashir, 13 June 2015, ICC, Pre-Trial Chamber II, Decision following the Prosecutor's request for an order further clarifying that the Republic of South Africa is under the obligation to immediately arrest and surrender Omar Al Bashir, ICC-02/05-01/o9-242, www.icc-cpi.int/CourtRecords/CR2015_06500.PDF, accessed 25 April 2018 ('Bashir Decision of 13 June 2015').

3 Prosecutor v. Omar Hassan Ahmad Al Bashir, 4 March 2009, ICc, Pre-Trial Chamber I, Warrant of Arrest for Omar Hassan Ahmad Al Bashir, ICC-02/05-01/09-1, www.icc-cpi.int/ CourtRecords/CR2009_01514.PDF, accessed 25 April 2018; Prosecutor v. Omar Hassan Ahmad Al Bashir, 12 July 2010, ICC, Pre-Trial Chamber I, Second Decision on the Prosecution's Application for a Warrant of Arrest, ICC-02/05-01/o9-94, www.icc-cpi.int/CourtRecords/ CR2010_04826.PDF, accessed 25 April 2018. The ICC had requested State Parties to the ICC Statute to arrest him in the event that he came into their jurisdiction. The ICC's request was 
the ICC Pre-Trial Chamber was of the position that Bashir's immunities as a sitting head of State had effectively been set aside by UNSC Resolution 1593 (2005), which referred the situation of Darfur to the Prosecutor of the ICc. ${ }^{4}$

The ICC's decision was in turn given effect the next day by a decision of the Gauteng Division of the South African High Court, which demanded the South African Government ('sA Government') to take all necessary steps to prepare for the arrest and detention of Bashir pending a formal request for his surrender from the ICc. ${ }^{5}$ The High Court further ordered the sA Government to take all required steps to prevent Bashir's departure and, to that end, directed the Government to effect service of the order on the officials in charge of every point of entry into and exit from the Republic. ${ }^{6}$ As is now well known, the SA Government failed to abide by those orders and reportedly facilitated Bashir's departure from South Africa. ${ }^{7}$

During domestic proceedings assessing the legality of its conduct, the SA Government argued that it had been caught in a legal bind consisting of two conflicting international obligations: first, its obligation to recognise Bashir's immunities as head of State as well as adhering to its agreement with the $\mathrm{AU}$ to provide immunity from arrest and detention to all attendees of the $\mathrm{AU}$ summit; ${ }^{8}$ and second, its obligation to arrest and surrender Bashir pursuant to the ICC's Bashir Decision of 13 June $2015 .^{9}$

made under the ICC Statute and with reliance on United Nations Security Council Resolution 1593 (2005), in which the UNSC had referred the situation of Darfur (Sudan) to the ICC for investigation and prosecution in accordance with the Chapter vII of the UN Charter.

4 Bashir Decision of 13 June 2015, supra note 2, paras. 7-8.

5 Southern Africa Litigation Centre v. Minister of Justice and Constitutional Development and Others, (Case No. 27740/2015), High Court of South Africa, 24 June 2015, ZAGP PHC (2015) 402 ('HCSA Judgment').

6 Ibid.

7 See Ventura, supra note 1, pp. 1022-1023.

8 Under Article viII of the 'Agreement between the Republic of South Africa and the Commission of the African Union on the Material and Technical Organisation of the Meetings of the $3^{\text {th }}$ Ordinary Session of the Permanent Representatives Committee from 7 to 9 June 2015 $27^{\text {th }}$ Ordinary Session of the Executive Council from 10 to 12 June 2015 and the $25^{\text {th }}$ Ordinary Session of the Assembly on 14 to 15 June 2015 in Pretoria (7 and 9 June 2015) and Johannesburg (10 to 15 June 2015), Republic of South Africa' (on file with the author), privileges and immunities were provided for the duration of the meeting to the members of the AU Commission and staff members including, as submitted by the sA Government, the delegates and other representatives of inter-governmental organisations attending the meetings. The immunities in question included immunity from arrest and detention.

9 See generally du Plessis, supra note 1. 
The Government's arguments were rejected by both the High Court ${ }^{10}$ and the Supreme Court of Appeal ('SCA'). ${ }^{11}$ Whilst their reasoning is not entirely consistent, both courts took the view that the Government had acted unlawfully when it failed to arrest President Bashir, with the SCA finding that the failure was inconsistent with South Africa's obligations in terms of the Rome Statute and section 10 of the Implementation of the Rome Statute of the International Criminal Court Act 27 of 2002 ('ICC Act'), and unlawful. ${ }^{12}$

Although it initially sought to challenge the judgment of the SCA before the Constitutional Court, the SA Government subsequently withdrew its application for leave to appeal on 21 October 2016 without providing reasons. ${ }^{13}$ Despite that withdrawal, the SA Government continued to argue that it had acted lawfully in giving preference to Bashir's immunities over its ICC obligations. ${ }^{14}$ It did so in proceedings before the Pre-Trial Chamber of the ICC under Article 87(7) of the ICc Statute. The Pre-Trial Chamber rejected South Africa's argument and found that South Africa was under a duty to comply with the Court's request for the arrest and surrender of Bashir. While that decision was not appealed by South Africa, a similar finding by the Pre-Trial Chamber (composed of the same three judges) in respect of Jordan's failure to arrest Bashir has been appealed by Jordan and will be heard by the Appeal Chamber during the course of $2018 .{ }^{15}$ We do not intend to discuss these Pre-Trial Chamber

10 HCSA Judgment, supra note 5.

11 Ibid.

12 See Minister of Justice and Constitutional Development and Others v. The Southern Africa Litigation Centre and Others, (Case No. 867/15), Supreme Court of Appeal of South Africa, 15 March 2016, ZASCA (2016) 17 ('scA Judgment').

13 See South African Department of Justice and Constitutional Development, 'Minister Michael Masutha: Media briefing on International Criminal Court and Sudanese President Omar Al Bashir', 21 October 2016, www.gov.za/speeches/minister-michael-masutha -media-briefing-international-criminal-court-and-sudanese-president, accessed 6 May 2018; M. du Plessis and G. Mettraux, 'South Africa's Failed Withdrawal from the Rome Statute - Politics, Law and Judicial Accountability', 15(2) JICJ (2017) 361-370.

14 See Prosecutor v. Omar Hassan Ahmad Al Bashir, 17 March 2017, ICC, State Representatives, Submission from the Government of the Republic of South Africa for the purposes of proceedings under Article 87(7) of the ICC Statute, ICC-02/05-01/o9-290, www.icc-cpi .int/CourtRecords/CR2017_01350.PDF, accessed 25 April 2018 ('Bashir Decision of 17 March 2017').

15 Prosecutor v. Omar Hassan Ahmad Al Bashir, 12 March 2018, ICC, Appeals Chamber, The Hashemite Kingdom of Jordan's appeal against the 'Decision under article 87(7) of the Rome Statute on the non-compliance by Jordan with the request by the Court for the arrest and surrender o[f] Omar Al-Bashir', ICC-02/o5-01/o9-326, www.icc-cpi.int/ CourtRecords/CR2018_01658.PDF, accessed 25 April 2018. 
findings in this article, since the Jordan and South African Decisions are clearly not the ICC's final word on the subject.

\section{A New Approach to Considering the Relationship between Immunities and International Crimes}

\subsection{The Traditional Approach}

The present article proposes to explore the unsettled relationship between immunities and international crimes by using a different lens than is traditionally relied upon to analyse the issue. The traditional approach is built around three core assumptions: the first is that the law of immunities consists of a unitary set of rules and principles, which are equally pertinent regardless of the context in which they apply. This core set of norms in turn revolves around a distinction between: (i) functional and personal immunities and (ii) official and private acts, as well as focusing on the State as the primary entity of legal relevance to this issue. The second basic assumption underlying the traditionalist approach is that this general framework is relevant, applicable and sufficient to address the conflict between immunities and international crimes without the need to account for any peculiarity attaching to the matter being regulated.

\subsection{Testing and Verifying the Assumptions against Relevant State Practice}

This article proposes to test these assumptions with a view to answering a number of basic questions: When it comes to international crimes, does the immunity regime apply in this penal context in exactly the same way as it would in other contexts? Has international criminal law evolved and developed on the question of immunities in the same way as other parts of international law or does its historical developments reveal a different approach to the question? Has international criminal law adopted the same articulation (functional/personal; official/private; state-focused) to resolving the legal tension between immunities and international crimes?

Each of these questions will be considered from the vantage point of international criminal law. By using a penal lens, one may thus divide up the exercise of evaluating the state of law in relation to each of the possible functions that immunities may play in the penal context - as a defence; as a bar to jurisdiction; and as an exception to an obligation to provide judicial assistance to another state or jurisdiction. Such an approach addresses and tests the assumption that the law of immunities developed in this penal environment no differently than in other relevant legal contexts. 
The proposed approach also provides a framework within which incidents of state practice and precedents can be evaluated in concreto, i.e., in relation to the particular aspect(s) of the question of immunities to which they relate and not, as sometimes performed, as if different aspects of the question of immunities could be rolled into one. Thus, for instance, the Pinochet, ICJ Arrest Warrant Judgment and the Bashir decisions of the South African courts are not generic precedents on immunities. They pertain to the narrow issue of the effect of immunities on the duty of a state to respond to a request for judicial assistance (regarding arrest and transfer) emanating from another jurisdiction. In contrast, other precedents (e.g., in the Taylor or Milosevic proceedings) touch upon the question of whether sovereign immunities could ever be raised as a defence to charges involving international crimes or could serve as a bar to jurisdiction. It is critical to the understanding of the law of immunities in relation to international crimes to assess those precedents in light of the actual question which they each raised and in light of the legal principles which they thus reflect. We thus take seriously what Lord Steyn rightly stressed in Daly: 'In law context is everything.' ${ }^{6}$

This article, therefore explores the question of the relationship between immunities and international crimes within the peculiar framework of the historical evolution of the law of immunities in international criminal law. For that purpose, it goes back to perhaps the first discussion of the issue in the aftermath of the First World War and travels through decades of judicial pronouncements and eventual crystallisation of certain customary law principles. This historical approach allows for an evaluation of the question of whether the law of immunities applying in this peculiar penal environment has in any way been shaped by it and, if so, how.

Relying on this novel approach, the paper concludes that international law provides for a clear delineation between immunities and international crimes: when confronted with international crimes, customary international law excludes immunities as a defence or as a bar to jurisdiction - regardless of the nature of the jurisdiction addressing the matter (national or international), regardless of the position of the accused (i.e., including heads of State) and regardless of whether the accused acted in a private or official capacity.

This approach also leads to the conclusion that in relation to a request for judicial assistance emanating from another jurisdiction (domestic or international), general international law does not as yet provide for a general exclusion of immunities, which remain applicable in principle but will not

16 Regina v. Secretary of State for the Home Department, Ex Parte Daly, United Kingdom House of Lords, 23 May 2001, 2 WLR (2001) 1622. 
provide a blanket objection to judicial cooperation in every case. In such a situation, as illustrated by the Bashir decisions of the South African courts, international law only provides for a general legal framework which must be supplemented by consideration of the laws of the jurisdictions concerned. Within that framework, where the Security Council has not explicitly set aside otherwise applicable immunities, the resolution of the legal tension between immunities and a duty to provide judicial cooperation would ultimately be regulated by the law of the requested jurisdiction, including any international obligation which might be binding upon that state as a matter of treaty or customary law.

\section{Immunities and International Crimes - Historical Overview}

\subsection{The Stakes}

Traditionally, international law granted absolute immunity to heads of State in respect of all commercial and criminal acts. ${ }^{17}$ Over time, international law has carved out a number of exceptions to the absolutist position. ${ }^{18}$ As will be argued below, one such exception, which now forms part of customary international law, is that immunities (including immunities of heads of State) are unavailable as a defence or jurisdictional bar to charges involving allegations of international crimes. This narrow exception to the principle of sovereign immunities grew contemporaneously with the idea that individuals, regardless of rank or position, could be held criminally responsible for acts committed in violation of international law. That process commenced in the immediate aftermath of the First World War and was fully settled by the end of the Second World War when a principle had crystallised pursuant to which immunities could not operate as defence or as bar to jurisdiction to charges involving allegations of international crimes.

In contradiction to that view, a number of national courts have continued to suggest that immunities ratione personae could still operate to shield (sitting) heads of State and other State officials from the jurisdiction of those domestic

\footnotetext{
17 See, e.g., H. Fox, The Law of State Immunity (oup, Oxford, 2008) p. 686; R. Pedretti, Immunity of Heads of State and State Officials for International Crimes (Brill-Nijhoff, Leiden, 2013), p. 13.

18 See, e.g., J. Foakes, The Position of Heads of State and Senior Officials in International Law (oup, Oxford, 2014), pp. 83, 89-96, and references therein; R. Van Alebeek, The Immunity of States and their Officials in International Criminal Law and International Human Rights Law (oup, Oxford, 2008).
} 
courts or as a defence to their prosecution for such crimes. ${ }^{19}$ The correctness of that view will be challenged as it appears to be built upon the false assumption that international law ever entertained the possibility of immunities as a defence or bar to jurisdiction for criminal charges involving international crimes, and because of a systematic failure on the part of these courts to distinguish between the different functions that international law assigns to immunities in the particular context of international criminal law.

\subsection{The First World War}

Following the First World War, an Inter-Allied Commission on the Responsibilities of War was established to look into the responsibility of the 'authors of the war'. In its Report, the Commission set out one of the first important challenges to the historical notion that State officials enjoy immunity from criminal prosecution when international crimes are at stake: ${ }^{20}$

The Commission desire to state expressly that in the hierarchy of persons in authority, there is no reason why rank, however exalted, should in any circumstances protect the holder of it from responsibility when that responsibility has been established before a properly constituted tribunal. This extends even to the case of heads of States. An argument has been raised to the contrary based upon the alleged immunity, and in particular the alleged inviolability, of a sovereign of a State. But this privilege, where it is recognized, is one of practical expedience in municipal law,

19 Re General Shaul Mofaz, UK District Court (Bow Street), 12 February 2004, ILDC (2004) 97; and C. Warbrick, 'Immunity and International Crimes in English Law', 53(3) Int'l \& Comp. L.Q. (2004) 769-774; Gaddafi case, Arrêt n ${ }^{\circ} 1414$ du 13 mars 2001 Cour de cassation Chambre criminelle [French Court of Cassation], 13 March 2001, translated and re-printed in 125 ILR (2001) 456 (unreasoned and un-sourced); Tatchell v. Mugabe, uk Magistrates' Court (Bow Street), 14 January 2004, 136 ILR (2004) 572; Vallmajo I Sala v. Kabarebe, Order No. 3/2008, Audiencia Nacional [National Court of Spain], 6 February 2008, ILDC (2008) 1198 (ES 2008), para. 4 in particular; In re Fidel Castro, Order No. 1999/2723, Audiencia Nacional [National Court of Spain], Sal de lo Penal, 4 March 1999, 32 ILM (1999) 596 (both of these decisions and others to the same effect rendered by Spanish courts are discussed in Pedretti, supra note 17, p. 143); Tachiona v. Mugabe, us Southern District of New York, 30 October 2001, 169 F. Supp. 2 d (2001) 25.

20 Commission on the Responsibility of the Authors of the War and on Enforcement of Penalties, 'Report Presented to the Preliminary Peace Conference', 29 March 1919, re-printed in 14(1) American Journal of International Law (1920) 95-154, at 116 ('Commission Report'). See also History of the United Nations War Crimes Commission and the Development of the Laws of War, compiled by the United Nations War Crimes Commission (H.M. Stationery Office, 1948), pp. 263-265 ('History of UNWCC'). 
and is not fundamental. However, even if, in some countries, a sovereign is exempt from being prosecuted in a national court of his own country the position from an international point of view is quite different.

On the above premise, a majority of State representatives on the Commission recommended the establishment of a High Tribunal composed of members of the victorious powers to try Kaiser Wilhelm II, Germany's fallen head of State. Under the proposed scheme, it was considered that his immunity would be no obstacle to prosecution..$^{21}$ The American and Japanese representatives on the Commission dissented on this point and took the view that heads of State, members of government and other high officials could not be held legally responsible before a judicial authority other than before their own national courts. ${ }^{22}$

Subsequently, at the 1919 Paris Peace Conference, the Allied Powers set out to establish the legal and jurisdictional framework for the Kaiser's trial, ${ }^{23}$ adopting the position that immunities were no valid objection to the prosecution of a head of State where the charges pertained to violations of international law. ${ }^{24}$ British Prime Minister, David Lloyd George, outlined the philosophy underpinning this position: 'I do not know why we should prescribe limits of punishment at the present stage ... Kings have been tried and executed for offences

21 Commission Report, supra note 20. The Commission also said the following in relation to the situation of the Kaiser: 'In view of the grave charges which may be preferred against to take one case - the ex-Kaiser - the vindication of the principles of the laws and customs of war and the laws of humanity which have been violated would be incomplete if he were not brought to trial and if other offenders less highly placed were punished. Moreover, the trial of the offenders might be seriously prejudiced if they attempted and were able to plead the superior orders of a sovereign against whom no steps had been or were being taken' (ibid., p. 117).

22 See 'Annex II: Memorandum of Reservations Presented by the Representatives of the United States to the Report of the Commission on Responsibilities', 4 April 1919, re-printed in 14(1) American Journal of International Law (1920) 127-151. The American objection was primarily grounded in concern for the absence of valid precedent that would provide for the possibility of making a head of State responsible to laws and tribunals other than those of his own country (ibid., p. 135). See also 'Annex III: Reservations by the Japanese Delegation', 4 April 1919, re-printed in 14(1) American Journal of International Law (1920) 151-152.

23 Article 227 of the Peace Treaty of Versailles (adopted 28 June 1919, entered into force 10 January 1920) provided for the arraignment and prosecution of Wilhelm II before a special tribunal where he would be tried for violating 'the solemn obligations of international undertakings and [...] international morality'. 
which are not comparable. [...] [W] e are making international law'. ${ }^{25}$ Nonetheless, despite those developments, Kaiser Wilhelm II continued to evade justice when the Netherlands refused to deliver him.

\subsection{From Nuremberg to The Hague}

The view that immunities could not serve as a defence or as an objection to jurisdiction when international crimes were at stake gained further recognition in the aftermath of the Second World War. An important contribution to that process was the London International Assembly's rejection of the 'traditionalist' view of immunities espoused by the American and Japanese delegates in $1919 .{ }^{26}$ Not long thereafter, in July 1943, the International Commission for Penal Reconstruction and Development presented its conclusions regarding the issue of immunities of heads of State and other State officials involved in violations of international law. ${ }^{27}$ Whilst members of the Commission adopted a variety of reasoning to arrive at their conclusions, the majority of them took the view that immunities did not and could not provide a bar to prosecutions for acts that would constitute violations of international law. ${ }^{28}$

The next body to grapple with the issue of immunities in relation to international crimes was the United Nations War Crimes Commission (UNWCC). The UNWCC took notice of the position of the Commission on the Responsibilities for the War that State officials, including heads of States, could not shelter behind their immunity in order to evade their individual responsibility under international law. ${ }^{29}$ Furthermore, having conducted a broad review of the evidence of crimes committed by the Nazi leadership, a sub-committee

25 J.F. Willis, Prologue to Nuremberg - The Politics and Diplomacy of Punishing War Criminals of the First World War (Greenwood Press, Westport, 1982), p. 57 (footnote omitted).

26 The London International Assembly was created under the auspices of the League of Nations Union by Viscount Cecil of Chelwood. It was a semi-official body whose members had been designated by the Allied governments present at the time in London. Its role was to make recommendation to these governments including as regard the question of liability of suspected war criminals. See History of UnWCC, supra note 20, p. 99 et seq., in particular pp. 101-102, 266.

27 The Commission was established by the nine States which had signed the St. James Declaration of 13 January 1942.

28 See History of UnWCC, supra note 20, p. 266. See also International Commission of Penal Reconstruction and Development: Proceedings of the Conference Held in Cambridge on the $14^{\text {th }}$ November, 1941, Between Representatives of Nine Allied Countries and of the Department of Criminal Science in the University of Cambridge, p. 11.

29 History of UnWCC, supra note 20, p. 268 ('The principle that such administrators, including heads of States and members of Governments, could not shelter under the cloak of immunity, was clearly established by the majority of the Commission's members'). 
of the UNWCC came to the view that all those involved in the planning and implementation of these crimes - including cabinet ministers and State administrators, including Hitler and Mussolini - would, as a matter of international law, be deprived of the benefit of immunity-based defences so that any such individual could be placed on a list of suspected 'war criminals'. ${ }^{30}$ That view was later re-affirmed in a number of surrender documents ${ }^{31}$ and other instruments calling for the arrest, transfer and prosecution of State officials. ${ }^{32}$ No distinction was ever drawn in that context between immunities ratione personae and ratione materiae; no suggestion was made that such a position would only apply to an international tribunal.

This principle of inapplicability of immunities as defence and bar to jurisdiction was later reflected in Article 7 of the Charter of the Nuremberg Tribunal which provided for an absolute exclusion of immunities as a defence or bar to jurisdiction for those to be tried before the Tribunal. Article 7 - as well as Article 6 of the Tokyo Charter - meant that 'within the sphere of crimes covered by the two Charters [crimes against peace; crimes against humanity; and

$30 \quad$ See ibid., pp. 268-269 (footnote omitted) ('As a result of these findings, the Commission and its Committee on Facts and Evidence adopted the rule of placing such persons on war criminals lists, and consequently of rejecting as irrelevant the doctrines of immunity of heads of State and members of Government, and of acts of State. Upon charges presented by various nations, Hitler was placed on the Lists of War Criminals on several occasions, and so were other high State administrators, such as Mussolini. The number of such accused persons increased in the course of time, and separate Lists of major or arch criminals were issued to deal exclusively with State administrators and other high officials')

31 See, e.g., Declaration regarding the defeat of Germany and the assumption of supreme authority with respect to Germany by the Governments of the United States of America, the Union of Soviet Socialist Republics, the United Kingdom and the Provisional Government of the French Republic, 5June 1945, avalon.law.yale.edu/wwii/gero1.asp, accessed 13 May 2018, which set out the unconditional surrender of Nazi Germany and provided the following: 'The principal Nazi leaders as specified by the Allied representatives, and all persons from time to time named or designated by rank, office or employment by the Allied representatives as being suspected of having committed, ordered or abetted war crimes or analogous offences, will be apprehended and surrendered to Allied representatives'.

See, e.g., Protocol of the Proceedings of the Berlin Conference, 2 August 1945, re-printed in 1(3) International Law Quarterly 1947, 415-432: 'War criminals and those who have participated in panning or carrying out Nazi enterprises involving or resulting in atrocities or war crimes shall be arrested and brought to judgment. Nazi leaders, influential Nazi supporters and high officials of Nazi organisations and institutions, and any other person dangerous to the occupation or its objectors, shall be arrested and interned'; Potsdam Declaration, 26 July 1945, www.ndl.go.jp/constitution/e/etc/co6.html, accessed 13 May 2018; Instrument of Surrender (Surrender of Japan), 2 September 1945, http://avalon.law.yale .edu/wwii/j4.asp, accessed 13 May 2018. 
war crimes], the doctrines of acts of State and of immunity of heads of State and State administrators were no longer relevant or operative as a basis for freeing the individuals concerned from penal responsibility'. ${ }^{33}$ As explained by Justice Robert H. Jackson, who was responsible for negotiating the Nuremberg Charter on behalf of the United States, the setting aside of immunities in this context was considered a practical necessity to making the prohibition on international crimes effective and all-encompassing. ${ }^{34}$

During the trials of the major Nazi war criminals, the Nuremberg Tribunal unambiguously rejected any suggestion that defendants would be entitled to claim immunities as a defence or as bar to the Tribunal's jurisdiction: ${ }^{35}$

The principle of International Law, which under certain circumstances protects the representatives of a State, cannot be applied to acts which are condemned as criminal by International Law. The authors of these acts cannot shelter themselves behind their official position in order to be freed from punishment in appropriate proceedings. [...] [T]he very essence of the Charter is that individuals have international duties which transcend the national obligations of obedience imposed by the individual State. He who violates the laws of war cannot obtain immunity while acting in pursuance of the authority of the State if the State in authorizing action moves outside its competence under International Law.

Referring to the Nuremberg Tribunal's holding, the UNWCC noted that a remarkable feature of the Nuremberg Judgment was that 'the irrelevance of the

History of UNWCC, supra note 20, p. 271.

34 'Report to the President by Mr. Justice Jackson, June 6, 1945', in Report of Robert H. Jackson, United States Representative to the International Conference on Military Trials, London, 1945 (U.s. Government Printing Office, 1949), p. 46: 'Nor should such a defense [pursuant to which the accused could be shielded from liability based on his immunity] be recognized as the obsolete doctrine that a head of state is immune from legal liability. There is more than a suspicion that this idea is a relic of the doctrine of the divine right of kings. It is, in any event, inconsistent with the position we take toward our own officials, who are frequently brought to court at the suit of citizens who allege their rights to have been invaded. We do not accept the paradox that legal responsibility should be the least where power is the greatest. We stand on the principle of responsible government declared some three centuries ago to King James by Lord Chief Justice Coke, who proclaimed that even a King is still 'under God and the Law".). See also, generally, History of UnwCC, supra note 20, p. 262.

Trial of the Major War Criminals before the International Military Tribunal, Vol. I (Nuremberg, 1947), p. 223. 
doctrines of heads of State and State administrators was pronounced in regard to the whole field of international crimes covered by the Charter'. ${ }^{36}$ Thus, it was said, the historical doctrine of acts of State 'does not justify the commission by nations or individuals of crimes or other unlawful acts in the realm of international law' because it is inconsistent with the concept of international crime and of the individual responsibility of international criminals. ${ }^{37}$ Writing to the President of the United States after the trial, the principal American Judge at Nuremberg, Justice Francis Biddle, explicitly recognised that by that point in time " $[\mathrm{t}]$ he official position of defendants in their government is barred as a defense.'38

A similar exclusion of immunities as defence and bar to jurisdiction was subsequently adopted as part of the legal framework that would regulate national prosecutions of Nazi war criminals. ${ }^{39}$ As observed by the UNWCC, 'the trial of all these high officials is conducted on the basis of the rule that they do not enjoy immunity and cannot claim impunity on account of having acted in the course of their official functions.' ${ }^{40}$ This made it entirely clear that the exception to immunities as a defence and bar to jurisdiction was not limited to international tribunals but would also apply in national proceedings concerned with international crimes.

On 12 December 1950, the General Assembly of the United Nations adopted the Nuremberg Principles. ${ }^{41}$ Principle III encapsulates the same general

36 History of UnWCC, supra note 20, p. 273.

37 Ibid., pp. 19-20.

38 'Report from Francis Biddle to President Truman, 9 November 1946', xv(386) Department of State Bulletin (1946) 954 et seq.

39 See 'Control Council Law No. 10, Punishment of Persons Guilty of War Crimes, Crimes Against Peace and Against Humanity, 20 December 1945', 3 Official Gazette Control Council for Germany (1946) 50-55, Art. II(4)(a) ('Control Council Law No. 10'): 'The official position of any person, whether as Head of State or as a responsible official in a Government Department, does not free him from responsibility for a crime or entitle him to mitigation of punishment'.

40 History of UNWCC, supra note 20, p. 274. UNWCC, Law Reports of Trials of War Criminals, Vol. vi (London, 1948), pp. 50, 60-61; UnwCC, Law Reports of Trials of War Criminals, Vol. XIII (London, 1949), p. 117.

41 UNGa Resolution 95(I), Affirmation of the Principles of International Law recognized by the Charter of the Nürnberg Tribunal Resolution, 11 December 1946. See also, UNGA Resolution $488(v)$, Formulation of the Nürnberg Principles, 12 December 1950. Concerning the meaning and standing of these Principles, see generally A. Cassese, Introductory Note, Affirmation of the Principles of International Law recognized by the Charter of the Nürnberg Tribunal, General Assembly Resolution 95(I), legal.un.org/avl/ha/ga_95-I/ga_95-I. html, accessed 12 May 2018, noting that the General Assembly's 'affirmation' effectively 
exclusion of immunities as a defence and jurisdictional bar for crimes under international law. ${ }^{42}$ Like the Judgment and Charter of Nuremberg, that Principle is general in scope and contains no suggestion that it was intended to apply only to international tribunals. Under that Principle, the loss of immunities as defence or bar to jurisdiction is indeed caused by the fact that charges pertain to international crimes rather than by the character (national or international) of the jurisdiction called upon to adjudicate upon those crimes. ${ }^{43}$

Finally, the statutes of contemporary international and internationalized criminal tribunals all reflect the same principle and expressly exclude immunities as a defence and as a bar to jurisdiction, including for heads of States. ${ }^{44}$

helped crystallise these principles into customary law. In the Eichmann case, the Israeli Supreme Court similarly expressed the view that General Assembly resolution 95 (I) was evidence of the Nuremberg principles forming part of customary international law. Attorney General of Israel v. Adolf Eichmann, Supreme Court of Israel, 29 May 1962, 36 ILR 277 ('Eichmann Supreme Court Judgment'). See also Report of the Secretary-General pursuant to Paragraph 2 of Security Council Resolution 808 (1993) (s/25704), para. 35 ('s/25704'). International Law Commission, 'Principles of International Law Recognized in the Charter of the Nüremberg Tribunal and in the Judgment of the Tribunal', II Yearbook of the International Law Commission (1950) ('Principles of International Law'), Principle III: 'The fact that a person who committed an act which constitutes a crime under international law acted as Head of State or responsible government official does not relieve him from responsibility under international law'.

43 This indifference to the - international or domestic - nature of the jurisdiction concerned is also apparent from, inter alia, Article IV of the Convention on the Prevention and Punishment of the Crime of Genocide ('Genocide Convention'), opened for signature 9 December 1948, 78 U.N.T.S. 277 (entered into force 12 January 1951). In UNGA Resolution No. 96(I), The Crime of Genocide, 11 December 1946, the UN General Assembly also affirmed that 'genocide' is a 'crime under international law' and specified that that 'principal offenders and associates, whether private individuals, public officials or statesmen' must be punished for the commission of this crime. See also Attorney General of Israel v. Adolf Eichmann, District Court of Jerusalem, 11 December 1961, 36 ILR 1968 ('Eichmann District Court Judgment'). See also Arts. 7 and 8 of 'Draft Code of Crimes against the Peace and Security of Mankind', II(2) Yearbook of the International Law Commission (1996) ('Draft Code of Crimes'), which provide for the exclusion of immunities as a defence or bar to jurisdiction in relation to international crimes regardless of the domestic or international character of the jurisdiction concerned; International Law Commission, Text adopted by the Commission at its forty-eighth session, from 6 May to 26 July 1996 (A/51/10).

44 See in particular Statute of the International Criminal Tribunal for the Former Yugoslavia (as amended in 2002), Un Doc. S/RES/808 (1993), Article 7(2); Statute of the International Criminal Tribunal for Rwanda, Un Doc. s/Res/955 (1994), Article 6(2); Rome Statute of the International Criminal Court, opened for signature 17 July 1998, 2187 UNTs 3 (entered into force 1 July 2002), Art. 27 ('ICC Statute'); Statute of the Special Court for Sierra 
Particularly instructive are the statutory instruments of two domestic (but internationalized) tribunals, the Kosovo Specialist Chambers and the Extraordinary Chambers in the Courts of Cambodia. Both of them provide for the general exclusion of immunities as defence and as bar to jurisdiction, thereby further underlining the fact that the exclusion of immunities in these circumstances is not specific to international tribunals but to international crimes. ${ }^{45}$

\section{Customary Law Excludes Immunities as Defence or Bar to Jurisdiction}

\subsection{General Considerations}

It is apparent from the above review that since at least the end of the Second World War, the possibility of raising immunities as a defence or jurisdictional bar to charges involving allegations of war crimes, crimes against humanity or genocide has systematically been excluded. ${ }^{46}$

Leone, 16 January 2002, www.rscsl.org/Documents/scsl-statute.pdf, accessed 13 May 2018, Art. 6(2). It should be noted that these provisions were intended to reflect customary international law as existed at the time of their adoption. See s/25704, supra note 41 , paras. 29, 34-35, and 57-58. See also, to the same effect, the statements of members of the UN Security Council at the time of adoption of the ICTY Statute (S/PV.3217), 25 May 1993.

45 Republic of Kosovo, Law No. 05/L-053 on Specialist Chambers and Specialist Prosecutor's Office, www.kuvendikosoves.org/common/docs/ligjet/05-L-053\%20a.pdf, accessed 13 May 2018, Art. 16(1)(b) ('Kosovo Law on Specialist Chambers'); and Law on the Establishment of the Extraordinary Chambers, with inclusion of amendments as promulgated on 27 October 2004 (NS/RKM/1004/o06), www.eccc.gov.kh/sites/default/files/legal-documents/KR_Law _as_amended_27_Oct_2004_Eng.pdf, accessed 13 May 2018, Art. 29(2): 'The position or rank of any Suspect shall not relieve such person of criminal responsibility or mitigate punishment'. See also Regulation No. 2000/15 on the Establishment of Panels with Exclusive Jurisdiction over Serious Criminal Offences (UNTAET/REG/2000/15), 6 June 2000, Section 15 ('Irrelevance of official capacity').

46 See generally A. Cassese, International Criminal Law (oup, Oxford, 2008), p. 306 ('Cassese ICL'); Prosecutor v. Anto Furundžija, IT-95-17/1-T, ICTY, Judgment, 10 December 1998, para. 140 ('Furundžija Trial Judgment'). See also International Law Commission, Fifth report on immunity of State officials from foreign criminal jurisdiction, by Concepción Escobar Hernández, Special Rapporteur (A/CN.4/701), para. 221. It would seem reasonable to suggest that the crime of torture would also come within the list (as a self-standing international crime or as an underlying war crime or crime against humanity). See ibid., para. 224. It is more questionable whether this principle would apply to other categories of international crimes (e.g., piracy) or would-be international crimes (e.g., international terrorism; aggression). Ibid., paras. 222-224. 
There is further jurisprudential support for the view that such an exception to immunities now forms part of customary international law. In Eichmann, for instance, the Supreme Court of Israel took the view that the Nuremberg Principles, which contain an exclusion of immunities as defence and bar to jurisdiction, "have become part of the law of nations and must be regarded as having been rooted in it also in the past'. ${ }^{47}$ In Karadžić, the International Criminal Tribunal for the former Yugoslavia ('ICTY') noted that 'the official capacity of an individual even de facto in a position of authority - whether as military commander, leader, or as one in government - does not exempt him from criminal responsibility and would tend to aggravate it'.48 In Furundžija, the same Tribunal determined that Article 7(2) of its Statute (and Article 6(2) of the ICTR Statute), which provide for the exclusion of immunities as defence and bar to jurisdiction, 'are indisputably declaratory of customary international law'49 In Milošević, it was again noted that '[t]here is absolutely no basis for challenging the validity of Article 7, paragraph 2, [ІСту Statute] which at this time reflects a rule of customary international law' ${ }^{50}$ As will be discussed below, Article 27 of the ICC Statute now recognizes and gives effect to this customary law exclusion of immunities as a defence and bar to jurisdiction for the purpose of proceedings before the ICc..$^{51}$

Eichmann Supreme Court Judgment, supra note 41, p. 311. See also Eichmann District Court Judgment, supra note 41, on the rejection of the 'Act of State' doctrine.

48 'In the Matter of a Proposal for a Formal Request for Deferral to the Competence of the Tribunal Addressed to the Republic of Bosnia and Herzegovina in Respect of Radovan Karadžić, Ratko Mladić and Mićo Stanišić', IT-95-5-D, ICTY, Decision, 16 May 1995, para. 24.

Furundžija Trial Judgment, supra note 46, para. 140.

$50 \quad$ Prosecutor v. Slobodan Milošević, IT-02-54, ICTY, Decision on Preliminary Motions, 8 November 2001, para. 28, 26-34 ('Milošević Decision on Preliminary Motions'). See also Prosecutor v. Charles Taylor, SCSL-2003-01-I, SCSL, Decision on Immunity from Jurisdiction, 31 May 2004, para. 47 ('Taylor Decision on Immunity'), where the Appeals Chamber of the Special Court for Sierra Leone determined that since Nuremberg, the principle that sovereign immunities are not available as a defence to international crimes 'became firmly established' (and, ibid., paras. 52-53); Prosecutor v. Tihomir Blaškić, IT-05-14, ICTY, Judgement on the Request of the Republic of Croatia for Review of the Decision of Trial Chamber II of 18 July 1997, 29 October 1997, para. 41 ('Blaškić Appeals Chamber Subpoena Decision').

51 SeeProsecutorv. Omar Hassan AhmadAlBashir, 13 December 2011, ICC, Pre-Trial Chamber I, Corrigendum to Decision Pursuant to Article $87(7)$ of the Rome Statute on the Failure by the Republic of Malawi to Comply with the Cooperation Requests Issued by the Court with Respect to the Arrest and Surrender of Omar Hassan Ahmad Al Bashir, ICC-02/0501/og, www.icc-cpi.int/CourtRecords/CR2011_21750.PDF, accessed 25 April 2018, para. 43 
However, it is noted that the scope and effect of the above customary law exclusion does not import a general abrogation of immunities when international crimes are at stake. It only deprives an individual charged with an international crime of the possibility of putting forth immunities he might otherwise enjoy as a defence in his trial or as an exception to the jurisdiction of a court over his conduct. It cannot therefore be said from the above that there is a general, all-encompassing, international crimes exception to State immunities under customary international law.

\section{$4 \cdot 2$ \\ The Non-availability of Immunities as a Defence and Bar to Jurisdiction Applies Regardless of the National or International Character of the Jurisdiction Concerned}

There is no suggestion, including from the above-mentioned precedents, that the customary law exclusion of immunities as a defence or bar to jurisdiction would be applicable to international tribunals only. Instead, as outlined above, relevant practice either explicitly applies the principle of exclusion of immunities as a defence or bar to jurisdiction to both domestic and international jurisdictions or draws no distinction between domestic and international jurisdiction. ${ }^{52}$ Thus, as noted by the ICTY, where customary international law

('ICC Malawi Decision'): '[T] he Chamber finds that customary international law creates an exception to Head of State immunity when international courts seek a Head of State's arrest for the commission of international crimes'.

See generally Kosovo Law on Specialist Chambers, supra note X, Art. 16(1)(b); Control Council Law No. 10, supra note 39, Art. II(4)(a) (applicable to domestic tribunals); Genocide Convention, supra note X, Art. IV; Draft Code of Crimes, supra note 43, Arts. 7-8 (intended to apply to both international and domestic tribunals); Principles of International Law, supra note 41, Principle III. The Genocide Convention likewise supports the view that immunities would be unavailable as defence or bar to jurisdiction in relation to genocide charges whether the court concerned is a domestic or an international tribunal. See Articles IV and VI of the Convention. One domestic court has suggested, however, that immunities could only be set aside in domestic proceedings where the court's competence over acts of genocide is expressly provided for under the Convention, i.e., if the court concerned is that of the state in the territory of which the act was committed. See Court of Cassation of Belgium: H.S.A. et al., v. S.A. et al. (Decision Related to the Indictment of Ariel Sharon, Amos Yaron and Others) [12 February 2003], 42 ILM 596 (2003), in particular, pp. 10-11 ("Qu'il ressort de la combinaison de ces deux dispositions que l'immunité de juridiction est exclue en cas de poursuite devant les juridictions identifiées à l'article VI précité mais ne l'est pas lorsque la personne accusée est traduite devant les tribunaux d'un Etat tiers s'attribuant une compétence que le droit international conventionnel ne prévoit pas"). That restrictive view is unconvincing for a number of reasons. First, it mixes up the question of jurisdictional competence and that of immunities. As is reflected in 
is applicable, the exclusion of immunities as defence or bar to jurisdiction would normally be effective regardless of the international or domestic nature of the court making use of that customary law exclusion: ${ }^{53}$

The general rule under discussion [protecting in principle the internal organization of each sovereign State] is well established in international law and is based on the sovereign equality of States (par in parem non habet imperium). The few exceptions relate to one particular consequence of the rule. These exceptions arise from the norms of international criminal law prohibiting war crimes, crimes against humanity and genocide. Under these norms, those responsible for such crimes cannot

Article VI, the drafters of the Convention intended to limit the jurisdictional reach of the Convention to two categories of jurisdictions: an international penal tribunal and/ or a competent tribunal of the state in the territory of which the act was committed. In particular, it was the intention of the drafters not to have the Convention grant universal jurisdiction to states over acts of genocide. See, generally, W. Schabas, "Convention on the Prevention and Punishment of the Crime of Genocide, Paris, 9 December 1948" (available at: http://legal.un.org/avl/ha/cppcg/cppcg.html). Secondly, whilst the drafters of the Convention thus intended to restrict the jurisdictional reach of the Convention, nothing in the travaux suggest that they sought to restrict the effect of Article IV in a similar manner. Instead, that provision closely tracks and resemble the language used since the First World War and reflected, inter alia, in the Nuremberg Charter. It thus provides, on its face, for a general and jurisdictionally un-qualified exclusion of immunities as defence and bar to jurisdiction. See also N. Robinson, The Genocide Convention - A Commentary (Institute of Jewish Affairs, World Jewish Congress, New York, 1960), pp. 70-74 (suggesting also that the expression "constitutionally responsible rulers" was preferred to "Heads of State" to exclude monarchs from the reach of Article IV). Therefore, whilst the Convention limits the circumstances under which a state party could be jurisdictional competent on the basis of that treaty, it does not purport to restrict the applicability of the exclusionary principle reflected in Article IV. Nor, as is apparent from the practice of domestic jurisdictions, does the Convention exclude the possibility for a state to go beyond the terms of the Convention and to exercise its jurisdiction over acts of genocide committed outside of their territory. Therefore, where a domestic jurisdiction is competent under its own laws to prosecute acts of genocide - rather than as a result of the terms of the Convention immunities as defence and bar to jurisdiction would remain inoperative. The Convention thus supports the view that no distinction should be drawn between the domestic and international courts in regards to the inapplicability of immunities as defence or bar to jurisdiction for acts of genocide. And it provides no authority for the suggestion that this exclusion would depend on the jurisdictional basis upon which a national court has relied to exercise its competence over allegations of genocide. 
invoke immunity from national or international jurisdiction even if they perpetrated such crimes while acting in their official capacity.

From the point of view of international law, the determining factor in regard to the availability of immunities as defence or bar to jurisdiction is therefore the nature of the offence, not that of the tribunal hearing the case. ${ }^{54}$

As a result, the holding of the International Court of Justice (ICJ) in the Arrest Warrant case, ${ }^{55}$ according to which the Minister of Foreign Affairs of the Democratic Republic of the Congo enjoyed 'full immunity from criminal jurisdiction, 56 must be understood as referring strictly to the factual scenario that was before the Court, namely, the issuing and circulation of an arrest warrant by a domestic judge for charges involving international crimes. The case concerned a question of (horizontal) judicial assistance between States. It did not concern itself with, and provides no precedent for, a (vertical) situation involving a domestic jurisdiction on the one hand and an international one on the other. Nor was the ICJ asked to pronounce on the issue of the availability of immunities as a defence or as bar to jurisdiction. The ICJ held only that the warrant of arrest was invalid ${ }^{57}$ which further explains why, as the ICJ suggested, immunity is not to be equated with impunity: where an official can be brought before a competent jurisdiction on charges of international crimes, his immunity would provide no bar and no impediment to the exercise of jurisdiction over his conduct. ${ }^{58}$ In that case, had the Congolese Minister

54 See, e.g., Milošević Decision on Preliminary Motions, supra note 50, in particular paras. 32-33. See also Regina v. Bartle and the Commission of Police for the Metropolis and Others, Ex Parte Pinochet, United Kingdom, House of Lords, 25 November 1998, publications.parliament.uk/pa/ld199899/ldjudgmt/jd981125/pinoo1.htm, accessed 13 May 2018 ('Pinochet case'), in particular, the holding of Lord Slynn of Hadley in Pinochet where it was determined that 'there is ... no doubt that states have been moving towards the recognition of some crimes as those which should not be covered by claims of state or Head of State or other official or diplomatic immunity when charges are brought before an international tribunal'. Significantly, Control Council Law No 10 and its exclusion of immunity-based defence applied to proceedings before national, not international, tribunals. In the same way, national jurisdictions have formally acknowledged the applicability of that principle in the context of their domestic proceedings (see above).

Arrest Warrant of 11 April 2000 (Democratic Republic of the Congo v. Belgium), 14 February 2002, International Court of Justice, Judgment, I.C.J. Reports 2002, p. 3 ('ICJ Arrest Warrant case').

$56 \quad$ Ibid., para. 54

57 Ibid., para. $78(\mathrm{C})(2)(3)$.

$5^{8} \quad$ Ibid., para. 61. 
been on Belgian territory at the time, customary international law would not have provided a bar to his arrest or subsequent trial before a Belgian court.

Because the customary law exclusion of immunities as defence or bar to jurisdiction does not depend and is not affected by the national or international character of the jurisdiction concerned, the loss of immunities for these limited purposes is thus determined, not by the - national or international character of the tribunal trying such a defendant, but by the international character of the crime with which s/he is charged. ${ }^{59}$

\subsection{The Inapplicability of Immunities as Defence or Bar toJurisdiction is Materially and Personally Unqualified}

The next issue to be addressed is whether this customary law exclusion of immunities as defence and bar to jurisdiction applies to all State officials and to all types of activities or whether there are exceptions to this principle. In considering this issue, one has to give careful consideration to 'precedents' and not rely on decisions and holdings that say nothing about immunities as defence or bar to jurisdiction but touch upon other aspects of the immunity question.

As a starting point, one should note that all precedents which have been cited above and which deal with immunities as defence and bar to jurisdiction provide for no personal or material exception to the principle of exclusion of immunities for these limited purposes. Furthermore, there are clear

59 See however K. Ambos, Treatise on International Criminal Law, Vol 1: Foundations and General Part (OuP, Oxford, 2013), pp. 413 et seq., drawing a distinction between so-called 'vertical immunity' in relation to international tribunals and 'horizontal immunity' relevant to the interstate level and suggesting that there is no limitation to the par in parem non habet judicium principle comparable to Article 27 of the ICc Statute when it comes to domestic courts. As noted above, this view is not consistent with existing practice which has not articulated this limitation as applicable exclusively to international tribunals. Instead, authorities and precedents cited above all suggest that this limitation is of general application regardless of the (national or international) character of the tribunal. The fact that as a matter of practice, it fell in a majority of cases to international tribunals to apply it does not impact the general character of the principle. The view advanced by Professor Ambos is also questionable as it treats immunities in relation to international crimes as if it were an issue capable of a single, unified, solution whereas practice and precedents clearly distinguish between the three possible functions of immunities in that context: as defence; as bar to jurisdiction; and as an exception or objection to an obligation to cooperate or provide assistance. The proposed nuance between international (vertical) and domestic (horizontal) courts appears to be relevant only to the third of these questions - not to the first and second. 
jurisprudential indications that international law makes no exception to the exclusion of immunities as defence or bar to jurisdiction for any sort of act or any category of individuals. In the words of the ICTY Appeals Chamber, the loss of immunity for that limited purpose is triggered 'even if they perpetrated such crimes while acting in their official capacity'. ${ }^{\prime 0}$ Other precedents make it clear that the holding of an official position, including as head of State or head of government, at the time of commission of international crimes provide no exception to the exclusion of immunities as defence and bar to jurisdiction. ${ }^{61}$ Thus, the crimes for which Charles Taylor, Slobodan Milošević and, arguably some of Karl Doenitz's crimes, ${ }^{62}$ were committed at a time when they were sitting heads of State and the conduct underlying the charges against them pertain to acts carried out in the exercise of their official function. Likewise, Jean Kambanda was convicted by the ICTR for acts committed whilst he was prime minister of Rwanda and which pertained to the exercise of that mandate. ${ }^{63}$ Some defendants were even charged (e.g., Charles Taylor) or tried (e.g., Uhuru Kenyatta) for international crimes at a time when they were still sitting heads of State.

In sum, customary international law appears to draw no distinction for the purpose of this limited exclusion of immunities as defence and bar to jurisdiction between acts committed in a private or official capacity. Nor does it distinguish between or exclude any category of individuals from this exclusionary rule or draw any sort of distinction between former and sitting officials. Since at least the end of the Second World War, customary international law has excluded the possibility of a head of State and other State officials relying on immunities as a defence or as an objection to the jurisdiction of a tribunal before which $\mathrm{s} / \mathrm{he}$ appears on charges of international crimes. This is the case irrespective of whether the jurisdiction trying them is a domestic or an international one. Furthermore, one cannot rely on precedents that deal solely with other aspects of the immunity-question (e.g., issues of judicial assistance as in Pinochet, the Arrest Warrant or the Bashir case) or instruments that deal with neither of these specific issues (e.g., the Vienna Convention on Diplomatic Relations of 1961) to seek to import an exception or qualification

6o Blaškić Appeals Chamber Subpoena Decision, supra note 50, para. 41 (emphasis added).

61 See also ICC Malawi Decision, supra note 51, para. 36

62 Following the death of Adolph Hitler, Doenitz had briefly become head of state. See also G. Schwarzenberger, The Law of Armed Conflict - Volume 2 of International Law as Applied by International Criminal Courts and Tribunals (Stevens \& Sons Ltd, London, 1968), p. 508.

63 See Prosecutor v. Jean Kambanda, 97-23-s, ICTR, Judgment and Sentence, 4 September 1998. 
to the exclusion of immunities for the two limited purposes of their serving as defence or bar to jurisdiction where relevant practice clearly and explicitly provides for none.

Where international crimes are at stake, none of the instruments and relevant precedents dealing with the question of immunities as defence or bar to jurisdiction would provide support for a distinction between official and private acts of State officials. Nor do any of these draw a distinction between sitting and former State officials. The customary law exclusion of immunities as a defence and jurisdictional bar therefore appears to be absolute in its effect and pertains to any individual regardless of rank or position. As discussed further below, Article 27 of the ICC Statute recognizes and gives effect to this customary principle. ${ }^{64}$

To the extent that certain domestic jurisdictions have sought to carve an exception into that exception to sovereign immunities in order to protect heads of State and officials from the possibility of prosecution, they have done so in violation of existing law and without apparent consideration of the necessary distinction that must be drawn as a matter of international law between the three possible uses of immunities in relation to international crimes - as a defence to the charges; as a bar to jurisdiction; and as an objection or exception to a duty to cooperate in judicial assistance matters. International law does not provide an exception to the unavailability of immunities in relation to the first two. The third possible function of immunities will be discussed next.

Immunities and Judicial Assistance

5.1 The State of the Law

The loss of immunity-based defences and bar to jurisdiction under customary international law does not imply that immunities cannot and might not have a bearing on proceedings concerning international crimes, including where these proceedings are taking place before an international tribunal. ${ }^{65}$ As noted by Judge Shahabuddeen, 'there is no substance in the suggested automaticity

64 See ICc Malawi Decision, supra note 51, paras. 37-43.

65 See, e.g., The Prosecutor v. William Samoei Ruto and Joshua Arap Sang, 18 June 2013, ICC, Trial Chamber v(a), Decision on Mr Ruto's Request for Excusal from Continuous Presence at Trial, ICC-01/o9-01/11-777, www.icc-cpi.int/CourtRecords/CR2013_04536.PDF, accessed 25 April 2018, paras. 91 et seq. ('Ruto Decision') 
of disappearance of the immunity just because of the establishment of international criminal courts. 66

In particular, existing practice does not provide support for a suggestion that immunities are inapplicable or irrelevant in respect of requests for judicial assistance emanating from another jurisdiction, even where that request comes from an international tribunal. ${ }^{67}$ As held by the SCA in the Bashir matter, in the context of intra-jurisdictional requests for judicial assistance, customary international law does not provide for an all-encompassing international crime exception to sovereign immunities. ${ }^{68}$

Distinguishing between the various functions of immunities in regard to international crimes (as a defence; as bar to jurisdiction; as potential exceptions to judicial cooperation on the other) is therefore critical to understanding where and how far international law now regulates the relationship between immunities and international crimes.

\subsection{The Distinction between International and Domestic Courts}

On 23 July 2003, President Charles Taylor of Liberia filed a motion to quash the indictment and arrest warrant issued against him by the Special Court for Sierra Leone on grounds that both instruments were invalid and a violation of his immunity as a head of State. At the time of filing his motion, Taylor was still an incumbent and serving head of State. ${ }^{69}$

In resolving Taylor's challenge, the Special Court relied upon the ICJ's holdings in the Arrest Warrant case to suggest that '[t]he nature of the Tribunals has always been a relevant consideration in the question whether there is an exception to the principle of immunity'.70 The SCSL went on to consider whether it could be characterised as an international tribunal holding that the resolution of the matter 'turns to a large extent on the legal status of the

66 Prosecutorv. Radislav Krstić, IT-98-33-A, ICTY, Dissenting Opinion of Judge Shahabuddeen on Decision on Application for Subpoenas, 1 July 2003, para. 11 ('Judge Shahabuddeen Dissent'); see also L. Daqun, 'Has Non-Immunity for Heads of State Become a Rule of Customary International Law?', in M. Bergsmo and Y. Ling (eds.), State Sovereignty and International Criminal Law (Torkel Opsahl, Florence, 2012), pp. 55, 64 and 67-68.

67 See generally discussion of the Blaškić Appeals Chamber Subpoena Decision, supra note 50, below.

68 SCA Judgment, supra note 12, para. 84.

69 Prosecutor v. Charles Taylor, SCSL-2003-01-I, SCSL, Applicant's motion made under protest and without waiving of immunity accorded to a Head of State requesting the Trial Chamber quash the indictment and declare null and void the warrant of arrest and order of transfer and detention, 23 July 2003.

$70 \quad$ Taylor Decision on Immunity, supra note 50, para. 49. 
Special Court'. The SCSL proceeded to list a number of factors which it thought supported the view that it was an 'international court' for the purpose of dealing with Taylor's challenge, 'with all that implies for the question of immunity for a serving Head of State. ${ }^{71}$ To explain the importance of the distinction that it saw between domestic and international courts, the scsu Appeals Chamber held: ${ }^{72}$

\begin{abstract}
A reason for the distinction, in this regard, between national courts and international courts, though not immediately evident, would appear due to the fact that the principle that one sovereign state does not adjudicate on the conduct of another state; the principle of state immunity derives from the equality of sovereign states and therefore has no relevance to international criminal tribunals which are not organs of a state but derive their mandate from the international community. Another is as put by Professor Orentlicher in her amicus brief that: 'states have considered the collective judgment of the international community to provide a vital safeguard against the potential destabilizing effect of unilateral judgment in this area'.
\end{abstract}

According to that view, the SCSL was therefore not just exercising the jurisdictional competence of Sierra Leone, but also a broader, international, judicial mandate. The SCsL concluded that 'the principle seems now established that the sovereign equality of states does not prevent a Head of State from being prosecuted before an international criminal tribunal or court: ${ }^{73}$ Accordingly, it declared that Article 6(2) of its Statute did not conflict with any peremptory norm of international law so that Taylor's status as an incumbent (and, by then, former) head of State when proceedings were initiated against him was no bar to the jurisdiction of the court.

Whilst the ultimate conclusion of the Special Court appears to be correct it did have jurisdiction to try Taylor and his immunity as an incumbent or former head of State was no bar thereto - its reasoning is much less compelling. Taylor's submission went to two different aspects of the Court's jurisdiction: (i) the legality of his transfer to the court; and (ii) the legality of the Court's exercise of jurisdiction over him. The Arrest Warrant case, as relied on by the SCSL, was only relevant to the first, and not the second, of these questions. As discussed above, the ICJ only ruled upon the legality of Belgium's issuance and

\footnotetext{
$71 \quad$ Ibid., paras. $41-42$.

72 Ibid., para. $5^{1}$ (footnote omitted).

73 Ibid., para. 52.
} 
circulation of an arrest warrant and not whether Belgium was jurisdictionally competent to try the Congolese minister. The Special Court's reliance on the ICJ holding in regard to its discussion of its jurisdiction to try Taylor was therefore inapposite. Furthermore, the Arrest Warrant case does not contain the finding which the SCSL appears to imply, namely, that sovereign immunities lose all procedural pertinence if the requesting jurisdiction is 'international' in character. The scsL's decision may therefore be criticized for resolving this issue based on an improper understanding of the precedents relied upon. ${ }^{74}$

The ICJ's acknowledgment of the specificity of international criminal tribunals stands for the recognition that the raison d'être behind sovereign immunities does not operate vertically (in relation to an international tribunal) in the same way or to the same extent as it does horizontally (between two domestic jurisdictions). ${ }^{75}$ Where a State is asked to provide judicial assistance to an international criminal tribunal (e.g., in regard to arrest; transfer of an individual; freezing of assets; etc.), the requested State must take into account the fact that the rationale for permitting foreign State officials to raise personal immunity before national courts, namely respect for the equal and mutual sovereignties of states in their horizontal relations and the risk that national authorities might use prosecutions to unduly impede or limit a foreign state's ability to engage in international action, does not exist or at least does not apply to the same extent. ${ }^{76}$ The requested State must also consider the fact that international criminal tribunals typically operate on behalf of a multitude of sovereign States and that the interests which they seek to uphold reach well beyond the interests of any single nation. Therefore, in balancing conflicting legal obligations arising from a State's international obligations including its obligation to cooperate with an international criminal tribunal ${ }^{77}$ versus its

74 See also ICC Malawi Decision, supra note 51, paras. 34, 36 .

75 ICJ Arrest Warrant case, supra note 55, p. 3, in particular, paras. 6o-61. See also Blaškić Appeals Chamber Subpoena Decision, supra note 50, paras. 47, 54. See further Cassese ICL, supra note 46, pp. 346-347; B. Swart, 'International Cooperation and Judicial Assistance General Problems', in A. Cassese, P. Gaeta and J.R.W.D. Jones (eds.) The Rome Statute of the International Criminal Court: A Commentary (Oup, Oxford, 2002), pp. 1590-1605; and Ambos, supra note 59, pp. 413 et seq.

76 See Blaškić Appeals Chamber Subpoena Decision, supra note 5o, paras. 40-42, 47. See also Taylor Decision on Immunity, supra note 50, paras. 51-52; ICc Malawi Decision, supra note 51 , para. 34 .

77 For State Parties to the ICC, that obligation arises from the terms of the Statute itself. In case of referral by the UN Security Council, a similar obligation arises in relation to the referred State (e.g., Sudan in relation to Unsc Resolution 1593 (2005)). See generally D. Akande, 'The Effect of Security Council Resolutions and Domestic Proceedings on 
obligation to respect another State's sovereign immunities, the weight that the requested State should attribute to considerations of State sovereignty are less compelling where a request for assistance comes from an international tribunal as opposed to a request from another single State. Moreover, where the State considers that its obligation to cooperate with an international tribunal outweighs immunity considerations, it will not thereby engage its responsibility under international law.

In sum, as it currently stands, international law does not provide for a general international crimes exception that would render immunities of heads of State (and those attaching to other functions) irrelevant and inapplicable regardless of the context in which they are raised. This was duly noted by South African courts in the Bashir matter, which also made it clear that a State is therefore not entitled by reason of international law or, as explained below, as a result of the ICc Statute, to ignore the immunities attaching to a third State or its officials when requested to cooperate with an international criminal tribunal.

Immunities before the ICC

\subsection{Conflicting Icc Jurisprudence}

By joining the ICC, State parties have renounced the possibility of raising immunities as a ground for non-cooperation with the Court in relation to their own nationals. It is also generally accepted that this waiver of immunity vis-à-vis the Court has a collective effect in that a State party could not refuse to arrest or transfer an official from another State party on the basis that $\mathrm{s} / \mathrm{he}$ enjoys immunities..$^{78}$

State Obligations to Cooperate with the ICC', 10(2) JICJ (2012) 299-324 ('Akande Effect of sc Resolutions').

78 See, e.g., Attorney General et al. v. The Kenya Section of the International Commission of Jurists, (Civil Appeal 105 of 2012/Criminal Appeal 274 of 2011 Consolidated), High Court of Kenya, 16 February 2018, kenyalaw.org/caselaw/cases/view/148746/, accessed 6 May 2018, at p. 40 ('Kenya Appeals Decision'): 'By virtue of Article 27 [of the ICc Statute], all States Parties through ratification of the Rome Statute consent to waive any immunity under international law. This is the statutory basis for the requested State Party to arrest and surrender the wanted foreign Head of State of another State Party. Secondly and of more significance because Article 27(2) codifies rules of customary international law, it is our considered view that it applies even to Heads of State and officials of non-States Parties in situations envisaged under Article 87(5)(a)(b). under that Article the Court may invite any non-State Party to provide assistance on the basis of an ad hoc arrangement or agreement. As a matter of fact, where a non-State Party fails to comply with requests made 
In contrast, with regard to officials from a non-State party, it is generally accepted that a loss of their immunity could arise in the context of a referral of a situation by the Security Council to the ICc. ${ }^{79}$ However, the underlying reasoning for this proposition is set out in contradictory and rather unconvincing ICC jurisprudence. In two instances, the ICC has suggested that customary international law excludes the application of immunities generally in cases which concern crimes within the Court's jurisdiction. ${ }^{80}$ However, as discussed above, there is little or no support in state practice or opinio juris to credibly put forth such an all-encompassing proposition in matters of judicial assistance. In contrast, in other decisions, the ICC has suggested or implied that immunities are inapplicable in cases of referrals by the UN Security Council by reason of an implicit waiver of immunities. ${ }^{81}$ For reasons outlined below, such an approach is equally unconvincing.

\subsection{No Implied Waiver of Immunities by the Security Council}

Under the second strain of ICC jurisprudence, UN Security Council referrals under Chapter viI of the UN Charter would render the immunities of officials from the referred State inoperative before the Court. This is the jurisprudential position adopted by the Pre-Trial Chamber to suggest that Bashir's immunities did not provide a valid objection to South Africa's obligation to arrest and

pursuant to any such arrangement or agreement, the Court is permitted to inform the Assembly of States Parties or the Security Council just as it would do in the case of a State Party's failure'. See also P. Gaeta, 'Official Capacity and Immunities', in A. Cassese, P. Gaeta and J.R.W.D. Jones (eds.) The Rome Statute of the International Criminal Court: A Commentary (oup, Oxford, 2002), p. 992.

79 See also E. de Wet, 'The Implications of President Al-Bashir's Visit to South Africa for International and Domestic Law', 13(5) Journal of International Criminal Justice (2015) 1049-1071, at 1056, noting that '[n]othing in the ICC Statute can remove the immunity belonging to non-State Parties as that would create obligations for third states in violation of the pacta tertiis rule and also render Article 98 meaningless'. (footnote omitted)

80 See Icc Malawi Decision, supra note 51, paras. 34, 36 et seq. See also The Prosecutor v. Omar Hassan Ahmad Al Bashir, 13 December 2011, ICC, Pre-Trial Chamber I, Decision Pursuant to Article 87(7) of the ICC Statute on the Refusal by the Republic of Chad to Comply with the Cooperation Requests Issued by the Court with Respect to the Arrest and Surrender of Omar Hassan Ahmad Al Bashir, ICC-02/05-01/09-140, www.icc-cpi.int/CourtRecords/ CR2012_04203.PDF, accessed 25 April 2018, paras. 13-14.

81 See, e.g., The Prosecutor v. Omar Hassan Ahmad Al Bashir, 9 April 2014, ICC, Pre-Trial Chamber II, Decision on the Cooperation of the Democratic Republic of the Congo Regarding Omar Al Bashir's Arrest and Surrender to the Court, ICC-02/05-01/09-195, www .icc-cpi.int/CourtRecords/CR2014_03452.PDF, accessed 25 April, paras. 26 et seq. ('Bashir Decision of 9 April 2014'); Bashir Decision of 13 June 2015, supra note 2, paras. 6-9. 
surrender him to the Court. ${ }^{82}$ There are a number of reasons to question the validity of this approach in this particular case. ${ }^{83}$

First, despite the SA Government's concerns, ${ }^{84}$ it should be noted that it seems legally possible for the Security Council to endow an international tribunal with the power to operate despite or regardless of otherwise applicable sovereign immunities. ${ }^{85}$ Indeed it is reasonable to suggest that this is precisely the approach taken by the Security Council when adopting the Statutes of the ad hoc Tribunals. The Statutes of both Tribunals, which were annexed to and formed part of the Council's Resolution, expressly provide for the exclusion of immunities as a defence and bar to jurisdiction for those subject to the jurisdiction of these tribunals. ${ }^{86}$ Such a course of action by the Security Council does not amount to a waiver of immunity, which is a power exclusively enjoyed by the State in question. ${ }^{87}$ It simply authorises a tribunal to operate despite or regardless of otherwise applicable immunities. Nonetheless, whilst the setting aside of immunities by the Security Council is theoretically possible, this cannot be assumed or implied from the mere creation of an international

82 This approach enjoys some scholarly support. See generally R. Cryer, H. Friman, D. Robinson, and E. Wilmshurst, An Introduction to International Criminal Law and Procedure (cup, Cambridge, 2014), pp. 559-56o; D. Akande, 'The Legal Nature of the Security Council Referrals to the ICC and its Impact on Bashir's Immunities' 7(2) JICJ (2009) 333352; de Wet, supra note 79, pp. 1057-1063.

83 For a critique of that approach, see for example, D. Tladi, 'When Elephants Collide it is the Grass that Suffers: Cooperation and the Security Council in the Context of AU/ICC Dynamics' 7(3) African Journal of Legal Studies (2014) 381-398; see also P. Gaeta, 'Does President Al Bashir Enjoy Immunity from Arrest?', 7(2) JICJ (2009) 315-332, at 327-329 ('Gaeta Immunity').

84 Bashir Decision of 17 March 2017, supra note 14, para. 85.

85 See also de Wet, supra note 79, p. 1060.

86 ICTY Statute, Art. 7(2) and IстR Statute, Art. 6(2). As discussed below, this does not have the effect of rendering immunities altogether irrelevant to proceedings before these tribunals. S/25704, supra note 41, para. 55: 'Virtually all of the written comments received by the Secretary-General have suggested that the statute of the International Tribunal should contain provisions with regard to the individual criminal responsibility of heads of State, government officials and person acting in an official capacity. These suggestions draw upon the precedents following the Second World War. The Statute should, therefore, contain provisions which specify that a plea of head of State immunity or that an act was committed in the official capacity of the accused will not constitute a defence, nor will it mitigate punishment'.

87 See also International Law Commission, Third Report on the Immunity of State Officials from Foreign Criminal Jurisdiction, by the Special Rapporteur, Mr. Roman Kolodkin, 24 May 2001 (A/CN.4/646), paras 32 et seq. 
criminal tribunal or from the referral of a situation to the competence of the ICC. 88

Quid of the situation at hand? With specific regard to the referral of the situation of Darfur, one should first note and acknowledge that there is no explicit indication of such a waiver in the text of the Resolution. Nor is there such an indication in the record of the debates. ${ }^{89}$ And no indication by any of the States that cast a vote on this Resolution could be located that would support such a view. Instead, at least one of these States (Russia) appears to have taken the view that it did not vote on the Resolution with an understanding that the immunities of Sudanese officials were being set aside by the Council. ${ }^{90}$ Such

88 Judge Shahabuddeen Dissent, supra note 66, 1 July 2003, para. 11: 'International criminal courts are established by States acting together, whether directly or indirectly as in the case of the Tribunal, which was established by the Security Council on behalf of States members of the United Nations. There is no basis for suggesting that by merely acting together to establish such a court States signify an intention to waive their individual functional immunities. A presumption of continuance of their immunities as these exist under international law is only offset where some element in the decision to establish such a court shows that they agreed otherwise. It may be thought that, in the case of the Tribunal, Article 29 of the Statute shows that they agreed otherwise, but that provision is directed to an obligation to cooperate; that obligation can be satisfied by a binding order which does not involve criminal sanctions inconsistent with the traditional functional immunity of States. Neither is an agreement to waive that immunity shown by Article 7(2) of the Statute, which has already been dealt with. It is difficult to see what else in the Statute shows that the establishment of the Tribunal as an international criminal court indicated an intention by States to abandon their individual functional immunities'.

89 See however Akande Effect of sc Resolutions, supra note 77, p. 324.

9o Russia's position appears to imply that the referral of the situation of Darfur through Resolution 1593 (2005) does not relieve states of their obligation to comply with internationally recognised standards regarding immunities. During the Council's consideration of the Report of the ICC Prosecutor in relation to the situation in Darfur, the Russian representative to the Council emphasized 'the importance of the implementation by States of the relevant obligations regarding cooperation with the Court, while complying with norms of international law in the matter of immunity of senior State officials'. See Reports of the Secretary General on the Sudan (s/Pv.6887), p. 16. The Russian Federation made a similar statement the following year. See Report of the Secretary-General on the Sudan and South Sudan (s/PV.7080). See also D. Tladi, 'The ICC Decisions on Chad and Malawi: On Cooperation, Immunities and Article 98', 11(1) JICJ (2013) 199-221. Moreover, the ICC transmitted decisions on the non- cooperation of Malawi, Chad and the DRC to the Security Council. The Council has never acted on them. One possible reading of this (repeated) failure to act by the Council is that there is no non-compliance with its referral in Resolution 1593. See ibid. See also R. Dicker, 'The ICC and Double Standards of International Justice', in C. Stahn (ed.), The Law and Practice of the International Criminal 
practice is evidently relevant to interpreting the terms of the Resolution, ${ }^{91}$ and absent any indication that the Council waived immunities as part of its referral, the theory of implied waiver of immunities by the Council thus carries little weight and is more aspirational than an authoritative interpretation of the Resolution.

In the absence of any explicit acknowledgment of the Security Council positively lifting the immunities of Sudanese officials, it has been suggested that the lifting of immunities could be deduced from Sudan's legal obligation to 'cooperate fully' with the Court as provided in Resolution 1593 (2005). ${ }^{92}$ The argument is problematic for a number of reasons. Firstly, the two issues are legally distinct. Cooperation is an obligation owed to the court whilst immunities are a legal privilege associated with the sovereign equality of states. Legally speaking, the duty of cooperation and existence of immunities are not mutually exclusive. Stated otherwise, the existence of a duty to cooperate with a tribunal does not necessarily nullify immunities in relation to that tribunal. In the Blaškić case, for instance, the ICTY Appeals Chamber was tasked to consider whether the tribunal was entitled to issue subpoenas and binding orders to Croatian State officials, noting that pursuant to Security Council Resolution 827 (1993), Croatia was legally bound to cooperate with the ICTY. ${ }^{93}$ On the proposed reasoning, this should have meant that Croatia's sovereign immunities would have ceased to operate in relation to any request for cooperation emanating from the Tribunal. This view was rejected by the ICTY. Instead, despite Croatia's obligation to cooperate with the tribunal in accordance with the UNSC Resolution, the ICTY held that Croatian officials continued to enjoy 'functional immunities' so that a subpoena could not be issued to them directly. ${ }^{94}$

Court (oup, Oxford, 2015). Another possible interpretation of the Council's failure to act would be to highlight the discretion it enjoys to act (or not to act) upon such reports and that such failure does not therefore provide support for a legal position either way of the argument.

91 On the relevance of such statements to interpreting the Resolution, see Accordance with International Law of the Unilateral Declaration of Independence in Respect of Kosovo, 22 July 2010, International Court of Justice, Advisory Opinion, I.C.J. Reports 2010, para. 94.

92 See, e.g., Bashir Decision of 9 April 2014, supra note 81, para. 29. See also, adopting the Pre-Trial Chamber's reasoning on that point, de Wet, supra note 79, p. 1061. UnsC, S/Res/827 (1993), 25 May 1993, para. 4 ('unsC Resolution 827').

94 See Blaškić Appeals Chamber Subpoena Decision, supra note 50, para. 38 (footnotes omitted) and paras. 41-42. The possible co-existence of cooperation towards and international tribunal and immunities is also apparent form the practice of the United Nations in the context of proceedings before the ad hoc Tribunals (although the United Nations do not have, stricto sensu, an obligation to cooperate with the tribunals). For instance, UN 
The Blaškić case illustrates the fact that a duty to cooperate on the part of a State does not nullify immunities that benefit and apply to its officials. It also stands for the proposition that immunities remain legally relevant in the context of judicial assistance proceedings.

Secondly, the proposed approach appears to over-reach when it interprets the obligation to cooperate as suggesting that cooperation with an international tribunal is necessarily unconditional and requires that all other legal considerations be set aside. The duty to cooperate with an international tribunal does not operate in a legal vacuum. Rather, it is typically qualified and restricted in a number of ways to allow for other considerations to create exceptions or qualifications of the obligation to cooperate. ${ }^{95}$ Furthermore, cooperation is not unaffected by the legal context in which it is implemented. For instance, a State which is required to cooperate with an international tribunal is normally authorized to perform its duty within the framework of its own domestic laws. ${ }^{96} \mathrm{~A}$ duty to cooperate with an international criminal tribunal cannot therefore be equated with the abolition of all other relevant legal considerations that might restrict or qualify the duty to cooperate with an international tribunal.

Thirdly, even if one were to read the duty created upon Sudan to 'cooperate fully' as depriving it of the possibility of raising its own immunities as an

immunities will typically continue to apply in relation to proceedings before the ad hoc Tribunals although the UN has agreed to cooperate with an international tribunal (for instance, by providing information or enabling one of its officials to testify before them). See, e.g., Letter of Ralph Zacklin, 4 February 2003, in Prosecutor v. Brđanin and Talić and Prosecutor v. Krajišnik (on file with the authors); Letter of 14 May 2001 from Jean-Marie Guehenno, Under-Secretary-General for Peacekeeping Operations, to Graham Blewitt concerning the lifting of immunities over UN documents (on file with the authors). See also In the matter of El Sayed, 'Letter from the un to Judge Fransen, Pre-trial Judge, Re: Filing in response to the scheduling order of 16 November 2010', STL, 23 November 2010 (filed 2 December 2010).

95 See, e.g., ICC Statute, supra note 44, Art. 72 (providing for a 'national security' exception to the obligation of states to cooperate). See also IстY Rules of Procedure and Evidence (Iт/32/Rev.37), Rule 7o(B), which would enable a state to provide information only for the limited purpose of generating other information and thus, in effect, condition the nature and scope of its cooperation.

96 See, e.g., ICC Statute, supra note 44, Arts. 88, 89(1) and 93(1). However, as noted by the Blaškić Appeals Chamber, whenever such implementing legislation turns out to be in conflict with the spirit and the word of the Statute, 'a well-known principle of international law can be relied upon to prevent States from shielding behind their national law in order to evade international obligations' (Blaškić Appeals Chamber Subpoena Decision, supra note 50, para. 54). 
objection to cooperate with the Court, the obligation to cooperate that was at stake in this case was South Africa's, not Sudan's. The proposed interpretation of the Resolution would thus be without effect on South Africa's own obligations towards Sudan or the Court. As noted above, Resolution 1593 only affects the relationship between Sudan and the Court. It does not create obligations erga omnes nor inter partes between State Parties and the referred State which remains a third State for the purpose of the Statute. In other words, Resolution 1593 did not modify or qualify South Africa's legal obligations towards the Court or towards Sudan. They remained to be determined by its own laws and international law obligations, including those which it had contracted as a State Party to the ICC.

Finally, as noted above, where immunities have been set aside by the Council, the removal was done expressly and with an unquestionable intention to do so. ${ }^{97}$ This would support the view that, to be effective, the lifting of immunities by the Security Council would have to be both explicit and unambiguous.

It is telling in that regard that the South African courts in the Bashir matter did not assume or adopt the view that immunities had somehow been lifted by the Security Council. Instead, they considered what effect those immunities had on its obligation to cooperate with the ICC.

\subsection{Duty of Cooperation on a Referred State}

The legal effect of a referral upon a State is not to put the referred State in a situation legally comparable in all relevant respects with that of a State party. The referral does not, for instance, carry certain rights normally associated with the status of a State party including, for instance, the right to nominate candidates for judicial appointment or to participate and vote at the Assembly of State Parties. Nor does it carry the same range of obligations including, for example, the responsibility to contribute to the budget of the Court. Instead, a referral has the practical effect of endowing the Court with jurisdiction (materiae; loci; personae; and temporis) over the referred situation. This implies, inter alia, a loss of immunities as a defence and bar to jurisdiction for those nationals of the referred state suspected of committing crimes in the context of the referred situation in accordance with Article 27 of the Statute as this provision forms part of the Court's jurisdiction (ratione personae).

However, the issues concerning the Court's jurisdiction are distinct from issues concerning obligations of cooperation attaching to status of a referred

97 See s/25704, supra note 41, para. 55; and UNSC Resolution 827, supra note 93, referring explicitly to that Report. 
State. ${ }^{98}$ With regard to the latter, it is the operative referral resolution which primarily sets out the obligations attaching to the referred State. ${ }^{99}$ As noted above, a referral resolution could create an obligation to cooperate with the ICC, as set out in Resolution 1593 (2005) (for all UN members or selectively for some states $)^{100}$ and/or set aside immunities. It is also within the realm of reason that the Security Council could provide specific detail as to the impact of an obligation to cooperate in any particular case or in relation to a particular State. Absent such specification, the ICC will normally interpret the scope of this duty of cooperation for a referred State in the same way as would apply to a State party. ${ }^{101}$

Indeed, there is no ambiguity in relation to the fact that a Security Council Resolution does not confer or indeed transform the referred State into an ICC State party. ${ }^{102}$ The referred State remains a third State for the purpose of the ICC Statute although one with certain legal obligations owed to the Court by reason and within the limits of the Security Council Resolution, which are legally enforceable if necessary, through the Security Council pursuant to Article $87(7)$ of the ICC Statute. Those obligations are thus created vis-à-vis the ICC and do not create mutually enforceable legal obligations between the referred State and any other State.

Based on the above, the legal and practical effect of Resolution 1593 (2005) upon the immunities of Sudanese officials was to render those inapplicable as a defence or as a bar to jurisdiction for any such official who would be brought before the Court to be tried. It did not provide for a blanket and implicit setting aside of Sudanese immunities beyond that point. As Sudan remains a third State for the purposes of the ICC Statute, the referral did not have the effect

98 See generally Judge Shahabuddeen Dissent, supra note 66, para. 11 (cited above).

99 It is questionable whether a referral of the Council would, per se and without further specification, import an obligation to cooperate on the part of the referred state (or any other). See contra G. Sluiter, 'Obtaining cooperation from Sudan - Where is the law?', 6(5) JICJ (2008) 871-884, at 880, suggesting that silence on the part of the UNSC would import for the referred state the 'normal' regime of the Statute.

100 Thus, whilst the resolutions creating the Yugoslav and Rwandan Tribunals created an obligation to cooperate for all United Nations member-states, the Statute of the Special Tribunal for Lebanon (adopted by unsc Resolution 1757 (2007)) creates an obligation to cooperate for Lebanon only (Art. 15 STL Statute, annexed to Resolution 1757).

101 See, e.g., Prosecutor v. Saif Al-Islam Gaddafi and Abdullah Al-Senussi, 1 March 2013, ICC, Pre-Trial Chamber I, Decision on the 'Urgent Defence Request', ICC-01/11-01/11, www .icc-cpi.int/CourtRecords/CR2013_01730.PDF, accessed 25 April 2018, paras. 25, 27. See also Akande Effect of sc Resolutions', supra note 77 .

102 See also Gaeta Immunity, supra note 83, p. 324; de Wet, supra note 79, p. 1059. 
of rendering those immunities irrelevant for other states, in particular in the context of requests for surrender Sudanese officials emanating from the ICC. The implications of this are now considered from the point of view of Articles 27 and 98 of the ICC Statute.

\subsection{Article 27 of the Icc Statute - No Immunity Defence and No Jurisdictional Bar to Prosecution for State officials}

Article 27 of the ICC Statute is to be found in the section of the ICC Statute dealing with 'General principles of criminal law'. It is one of five successive statutory provisions - Articles 24 to 28 - concerned with the Court's jurisdiction ratione personae. It is therefore one of the provisions which regulates the scope of the Court's competence to try certain categories of individuals and which map out the jurisdictional conditions underlying the Court's authority to do so.

In this context, the purpose and function of Article 27 is two-fold: its first paragraph excludes immunities as a defence and thus eliminates for the purpose of establishing liability under the Statute any jurisdictional difference between those who acted in an official capacity and those who did not. ${ }^{103}$ Article $27(2)$, in turn, makes it clear that the official capacity in which an individual acted at the time relevant to the charges does not constitute a jurisdictional bar to his/her prosecution before the Court. ${ }^{104}$ In effect, Article 27 excludes the possibility for an ICC defendant to evade liability by reason of his/her official role or function and any immunity attaching thereto. It thus reflects the customary law principle stated above that an official position and related immunities offer no defence and no procedural bar to the Court's jurisdiction over an individual charged with committing a crime within the Court's jurisdiction. ${ }^{105}$

103 It also makes it clear that, as has been the case since Nuremberg, an official position offers no ground in mitigation of sentencing.

104 Professor de Wet has rightly noted that Article 27(2) would supersede and set aside immunities arising from both domestic and international law. See de Wet, supra note 79, p. 1055, pointing to the fact that Article 27(2) refers to immunities and special procedural rules 'under national or international law'.

105 See generally Ruto Decision, supra note 65, paras. 66 et seq. See also The Prosecutor v. Omar Hassan Ahmad Al Bashir, 4 March 2009, ICC, Pre-Trial Chamber I, Decision on the Prosecution's Application for a Warrant of Arrest against Omar Hassan Ahmad Al Bashir, ICC-02/05-01/o9, www.icc-cpi.int/CourtRecords/CR2009_01517.PDF, accessed 25 April 2018, paras. 41 et seq. ('Bashir Decision of 4 March 2009'); Bashir Decision of 9 April 2014, supra note 81, para. 34. See also SCA Judgment, supra note 12, para. 59. It would be wrong therefore to suggest that whilst an accused before the ICC loses the benefit of 
Article 27 clearly establishes that there is no difference, for the purpose of establishing responsibility before the Court, between a defendant who at the relevant time held an official position and one who did not. It creates jurisdictional equality, ratione personae, between these categories of individuals. The loss of immunities triggered by Article 27 results from the fact that the Court is jurisdictionally competent to try the accused. It is irrelevant for the purpose of that provision whether the accused is a national of a State party or a national of a non-State party as long as the Court has jurisdiction over his conduct. ${ }^{106}$ If the Court is jurisdictionally competent to prosecute an individual for his alleged crimes, an official position or an immunity the accused might otherwise have enjoyed will therefore have no bearing on the Court's jurisdiction and entitlement to try him regardless of his nationality or the fact that he holds the nationality of a State party.

As a jurisdictional provision, Article 27 only deals with the effect (or, rather, the absence of effect) of an official position and related immunities on the jurisdiction of the Court itself.107 It does not regulate, nor purport to regulate, the effect of these immunities on the jurisdiction of any other court.

\subsection{Article 98 of the Icc Statute - Requests for Assistance and Immunities of Third States}

Pursuant to Article 98(1) of the Statute, the Court may not proceed with a request for surrender or assistance which would require the requested State to act inconsistently with its obligations under international law with respect to the State or diplomatic immunity of a person or property of a third State. Article 98 thus provides for a blocking mechanism that sets a limit to the ability of the ICC to demand cooperation from a State in relation to the surrender of a suspect or other forms of assistance where such cooperation would affect

his immunities as defence and as bar to jurisdiction as a result of Article 27, he would still enjoy those as a matter of customary international law. Article 27 reflects and tracks customary international law on that point (see above). Therefore, a defendant appearing before the ICC would not be more entitled to his immunities before the ICC than he would before a court of law that would apply customary international law. See contra D. Tladi, 'The Duty on South Africa to Arrest and Surrender President Al-Bashir under South African and International Law: A Perspective from International Law', 13(5) JICJ (2015) 1027-1047, at 1037 .

106 This explains the reference in Article 27(1) to the fact that 'This Statute shall apply equally to all persons'. See also, e.g., Bashir Decision of 4 March 2009, supra note 105, para. 41.

107 See ICc Statute, supra note 44, Art. 27(2). 
the sovereign immunities of a third State. ${ }^{108}$ The ICC Statute does not therefore give State parties express or implied authority to disregard the immunities of another State. Instead, as is apparent from Article 98(1), it expressly reminds them that their statutory obligations must be interpreted in light of and accommodate their other international obligations including those arising from another State's sovereign immunities.

The first question to arise is whether, pursuant to that provision, it is for the requested State to determine whether its duty to cooperate with the Court would require it to act inconsistently with its other obligations under international law or whether this determination lies exclusively with the ICC. Arguably, Article 98(1) can be read either way. The ICC Prosecution has pointed to Rule 195 of the ICC's Rules of Procedure and Evidence to suggest that it is for the Court itself to make that determination. ${ }^{109}$ However, the text of that provision is inconclusive and may in turn provide support for the opposing position. Further consideration is therefore necessary.

It is apparent from a literal interpretation of Article 98 that the determination as to whether a request for surrender or assistance raises 'a problem of execution in respect of article 98 ' is to be made by the State concerned, not by the Court. Where the view is taken by the state concerned that this is the case, that State is then required to provide relevant information to enable the Court to seek to obtain the cooperation of that third State for the waiver of the immunity pursuant to the terms of that provision. Such an interpretation would appear to mirror the situation foreseen in Article 98 whereby a State is of the view that to proceed with a request for surrender or assistance would 'require [that] State to act inconsistently with its obligations under international law'.

Reference must also be made to the French text of Article 98 of the Statute. ${ }^{110}$ The French version of Article 98 makes it clear that the Court may not proceed

108 'Third state' is generally understood to exclude State Parties which are assumed to have collectively waived any claim to immunity pertaining to their nationals and State officials.

109 See Bashir Decision of 17 March 2017, supra note 14, para. 60: 'In terms of the application of article 98 , rule 195 of the Rules confirms that when a requested State raises a problem in respect of article 98, while it must provide relevant information to the Court, this is 'to assist the Court in the application of article 98'. As such, it emphasises that it is for the Court to determine whether the conditions in article 98(1) or (2) are met. Should the Court determine they are not, it may proceed with the cooperation request and the requested State Party must comply')

110 Rome Statute of the International Criminal Court, 17 July 1998, 2187(38544) Treaty Series (2004). (The original of the ICc Statute, where the Arabic, Chinese, English, French, Russian and Spanish texts are equally authentic.) See ibid., Art. 128. 
with the implementation of a request for surrender or assistance, ${ }^{111}$ where this would result in a violation of that State's international obligations. This must per force imply that prior to a State notifying the Court of any obstacles to its cooperation pursuant to Article 98 , the State in question is already of the position that the request for judicial assistance would require it to act in violation of its other obligations so that its implementation cannot proceed. On this reading, Articles 98 and Rule 195 would suggest again that it is for the State concerned, and not for the Court, to determine whether cooperation pursuant to Article 98 would require that State to act inconsistently with its obligations under international law.

In contrast to that view, one could point to Article 119 of the Statute, which provides that "[a]ny dispute concerning the judicial functions of the Court shall be settled by the decision of the Court'. Could one suggest, based on that provision, that is for the Court alone to decide whether or not it is impeded from cooperation? According to one view, Article 119 would give the Court exclusive competence to resolve a dispute arising from the implementation of a request for assistance. Several reasons militate against an interpretation of Article 119 which would result in the necessary conclusion that the question of the incompatibility foreseen in Article 98 is to be resolved exclusively by the Court. First, it is questionable whether such a matter is one that concerns 'the judicial functions of the Court (Art. 119(1)) as opposed to the judicial functions of the courts of the requested State. In this regard, it is worth recalling that African Ministers of Justice have in the past recommended that the issue of the relationship between Articles 27 and 98 of the ICC Statute be referred to the Assembly of States Parties in terms of Article 119 of the ICC Statute.12 This would suggest that this matter is one that would come within the scope of Article 119(2) of the Statute rather than Article 119(1).

There are other reasons to question the view that Article 119(1) endows the Court with the primary responsibility to make a determination of incompatibility pursuant to Article 98(1). First, such a determination requires an appraisal of that state's various international obligations. The Court typically would have little knowledge and understanding of what those obligations might consist of. In contrast, the state concerned would be fully apprised of the state of its international legal obligations. Secondly, this determination might involve an interpretation of what international law obligations are binding upon that

\footnotetext{
111 The relevant phrasing: 'ne peut poursuivre l'exécution d'une demande de remise ou d'assistance' (emphasis added).

112 See 'Ministerial Meeting of African States Parties to the Rome Statute of the ICC', 8-9 June 2009, Addis Ababa, MinICC/Legal (on file with the authors).
} 
State in accordance with its own domestic law (e.g., to determine whether an international obligation has been domesticated; or what constitutional rank an international obligation might have relative to another). In that context, one should note that the Court is competent under the Statute to apply and interpret its Statute and related Rules. It has been given no express statutory authority to apply or interpret the national law of a State concerned by its proceedings. ${ }^{113}$ To the extent that any such power were to be implied, international law principles would limit that authority to verifying the compatibility of the interpretation given by domestic courts of their own laws in light of that State's international obligations towards the Court. ${ }^{114}$ In accordance with this standard, it would therefore be for the State concerned to interpret its own laws in the first place. ${ }^{115}$ Such an interpretation would provide the starting point from which the Court could deviate only in exceptional circumstances where the interpretation offered by the State or by one of its organs is manifestly incorrect. ${ }^{116}$ In the case at hand, this would mean that the determination of

113 Article 21(1)(c) refers (residually) to the law of the state concerned in defining the court's jurisdiction. In contrast, no provision is made in the Statute for the Court to rely upon or interpret domestic law when it comes to issues of cooperation and judicial assistance (Part IX of the Statute). See also Articles 88, 89(1) and 93(1), introductory sentence, of the Statute.

114 See generally Certain German Interests in Polish Upper Silesia (Germany v. Poland), 25 August 1925, Permanent International Court of Justice, Judgment (Merits), PCIJ Series A No. 6, p. 19; Garcia Ruiz v. Spain, 21 January 1999, European Court of Human Rights, no. 30544/96, Reports of Judgments and Decisions 1999-I, para. 28. Compare also the opinion of Judges Lauterpacht and Quintana on this point in the Case concerning the Application of the Convention of 1902 governing the Guardianship of Infants (Netherlands v. Sweden), 28 November 1958, International Court of Justice, Judgment, I.C.J. Reports 1958, p. 55.

115 J. Crawford, Brownlie's Principles of Public International Law (oup, Oxford, 2012), pp. 53-54, referencing Ahmadou Sadio Diallo (Republic of Guinea v. Democratic Republic of the Congo), 30 November 2010, International Court of Justice, Judgment (Merits), I.C.J. Reports 2010, para. 70 ('Diallo Judgment, para. 70'); Panevezys-Saldutiskis Railway Case (Estonia v. Lithuania), 28 February 1939, Permanent International Court of Justice, Judgment, PCIJ Series $A / B$ No. 76 , p. 19 .

116 See, e.g., Markovic and others v. Italy, 14 December 206, European Court of Human Rights, no. 1398/03, Reports of Judgments and Decisions 2006-XIV, par 95. See also, Crawford, supra note 115, pp. 53-54 (referring again to the Diallo Judgment, supra note 115, para. 70; and Fraport AG Frankfurt Airport Services Worldwide v. Republic of the Philippines, ICSID Case No. ARB/03/25 (Annulment Proceeding), International Centre for the Settlement of Investment Disputes, Decision on the Application for Annulment of Fraport AG Frankfurt Airport Services Worldwide, 23 December 2010, www.italaw.com/sites/default/files/case -documents/ita0341.pdf, accessed 13 May 2018, paras. 236, 242). 
the compatibility of the ICC's request with South Africa's other international obligations would have had to be made by the competent authorities of that State and, therefore, ultimately, by its courts and could only be challenged by the Court if manifestly incorrect.

The better view, therefore, seems to be that it is for the requested State to first determine whether the implementation of a request for surrender or assistance under Article 98 would result in a violation of its other international obligations subject, perhaps, to the 'exceptional circumstances' reviewing authority of the Court. Where the State is of the reasonable view that the implementation of a request would have that effect, it must notify the Court in order to trigger the procedure provided by Article $98 .{ }^{117}$ Only where the position taken by the state is untenable from the legal point of view could the Court step in and impose its own interpretation. ${ }^{118}$ This is the position taken by both the South African and Kenyan courts in the matter Bashir.119

Pursuant to Rule 195, where a State has taken the view that the request is incompatible with its other international obligations for reasons related to the immunities of a third State, it would have to provide any information relevant to assist the Court in its application of Article 98 so that the Court may seek a waiver of immunities from the State concerned and, arguably, conduct the 'exceptional circumstances' review of the requested State's determination. Short of such waiver and perhaps short of an 'exceptional circumstances' determination by the Court, the ICC would lack the authority to order or force a State party to disregard or act in violation of the immunities of a third State. ${ }^{120}$

117 SCA Judgment, supra note 12, para. 78. Article 98(1) of the ICC Statute does not oblige the requested State to take any step to resolve that tension. It is also apparent from the text of Article 98(1) that if the Court fails to obtain a waiver of immunities from the third State, this would in turn preclude a finding of non-cooperation on the part of the requested State pursuant to Article 87(7). Under that provision, the requested state's failure to comply with the Court's request would not be 'contrary to the provisions of this Statute' but in accordance therewith. See ICC Statute, supra note 44, Art. 93(6) where a State refuses to provide cooperation: 'If a request for assistance is denied, the requested State Party shall promptly inform the Court or the Prosecutor of the reasons for such denial'. See also ibid., Art. 99 regarding the modalities of implementation of a request for assistance ('unless prohibited by such law').

118 See references in supra notes 114-115.

119 See generally Kenya Appeals Decision, supra note 78. See also discussion below.

120 See also ICc Statute, supra note 44, Art. 93(3). 

Appeal in the Bashir Case

The interpretation adopted by the SCA in the Bashir matter and its articulation of the relationship between international and domestic law is consistent with the demands of international law. ${ }^{121}$ The SCA was correct in concluding that neither general international law, nor the ICC Statute, provides a readymade answer to the legal challenge before it. The lawfulness of South Africa's response to the ICC's warrant stood to be determined on the basis of domestic law as interpreted in light of South Africa's international law obligations including those arising from the ICC Statute.

The scA rightly rejected any suggestion that international law prohibits South Africa from detaining and transferring Bashir to an international criminal tribunal such as the ICC. Neither customary international law nor the ICC Statute supports such an interpretation. Reliance on the ICJ's Arrest Warrant case to criticise the SCA's decision is inapposite. The Arrest Warrant case pertains to a situation where the arrest warrant comes from another domestic jurisdiction, not from an international tribunal - a factually distinct situation with different legal consequences. ${ }^{122}$ The ICJ did not suggest that where a request for assistance comes from an international criminal tribunal, immunities would or could ever supersede a binding obligation to cooperate with such a tribunal. Instead, the ICJ strongly hinted at the very opposite conclusion. ${ }^{123}$ This is the logical consequence of the fact that, when acting in response to a warrant from the ICC, a State party is effectively acting, not on its own behalf, but on behalf of a community of States and interests represented by the membership of that Court if not beyond it.

Furthermore, the SCA was also right to take the view that international law does not support a general suggestion that immunities would necessarily take precedence over South Africa's obligations to the ICC regardless of context and regardless of the stakes. Instead, in matters of judicial assistance and cooperation, in its current stage of development, international law leaves it to a State's domestic law to decide and to determine the ordering and hierarchy of that

\footnotetext{
121 SCA Judgment, supra note 12.

122 ICJ Arrest Warrant case, supra note 55, p. 3, in particular paras. 58, 61 and 51: '[I]n international law it is firmly established that ... certain holders of High-ranking office in a State, such as the Head of State ... enjoy immunities from jurisdiction in other States, both civil and criminal' (emphasis added).

123 Ibid., para. 61.
} 
State's international obligations if they conflict other than in respect of international norms of a higher standing, such as jus cogens norms.

The sCA correctly noted that, where a State party has been asked to cooperate with the ICC, a primary legal consideration which it will have to factor in its determination is the fact that the State is indeed bound to respect the terms of the Statute and, generally, to comply with requests for assistance from the ICc. ${ }^{124}$ That aspect of the legal equation requires the State to interpret its obligations towards the ICC in a way that maintains their effectiveness and that accounts for the peculiarity attaching to international criminal tribunals. ${ }^{125}$

A second important consideration in this context is the state of international law as regard the scope and effect of immunities upon a State's legal obligations. ${ }^{126}$ When addressing the 'narrow issue' of whether there is now a general, all-encompassing, international crimes exception to the principle of head of State immunity, the SCA responded with soberness and clarity: no such exception exists as customary international law stands today. ${ }^{127}$ The SCA noted that Article 27 of the ICC Statute did not have the effect of rendering immunities irrelevant nor does it permit State parties, in their relation with the Court, to ignore those immunities. ${ }^{128}$ As noted above, this provision has a narrower scope and function in that it excludes the possibility of immunities serving as a defence or as a bar to jurisdiction. It does not in any way affect or pertain to the question of immunities in the context of judicial assistance. This was duly noted by the SCA which correctly reflected that: ${ }^{129}$

There is a difference between saying that an international tribunal, having jurisdiction and constituted on terms that specifically exclude reliance on any principles of immunity, provides an exception to the customary international law rule that heads of state enjoy immunity ratione personae, and saying that a national court asked to provide assistance to that international tribunal is likewise not bound by the customary international law rule. It is the latter proposition with which we are concerned.

The SCA thus correctly understood that the ICC Statute was not dispositive of the matter and implicitly rejected the suggestion that immunities had

\footnotetext{
124 See generally sCA Judgment, supra note 12, para. 61.

125 Ibid., para. 90.

126 Ibid., paras. 66 et seq.

127 See ibid., in particular, para. 84. See also ibid., paras. 70 et seq.

128 Ibid., para. 69 .

129 Ibid., para. 77.
} 
been rendered inoperative by reason of the Council's referral. On that issue, the SCA found the answer, neither in the ICC Statute nor in a would-be, but non-existent, principle of customary international law. Instead, it found it in its own domestic laws, including the domesticated ICc Statute, which it read as providing no general exception to the country's obligation towards the ICC to surrender suspects when it concerns a sitting head of State. ${ }^{130}$ This, it concluded, meant that Bashir should have been detained and transferred to the jurisdiction of the ICC regardless of any immunity that he might otherwise have enjoyed.

The same general approach was adopted by the Court of Appeal of Nairobi which decided on the failure of the Kenyan Government to execute ICC warrants for the arrest of President Bashir. ${ }^{131}$ In its Judgment, the Court of Appeal first pointed out that " $\mathrm{t}$ ] he principle of individual criminal accountability for all who commit such acts was established as a cornerstone of international criminal law' ${ }^{132}$ Consistent with Rule 98 of the ICC, the Court of Appeal then noted that the ICC can request surrender or assistance only if it would not require the requested State to act inconsistently with its obligations under international law with respect to the State or diplomatic immunity of a person or property of a third State. In such a situation, it pointed out that the Court must first obtain the cooperation or consent of the third State or sending State for the waiver of the immunity. ${ }^{133}$ The Court of Appeal next pointed out that

130 See in particular SCA Judgment, supra note 12, para. 100.

131 See generally Kenya Appeals Decision, supra note 78.

132 Kenya Appeals Decision, supra note 78, p. 4. See also ibid., p. 45: 'We have no doubt that an exception to immunity exists in cases where the individual is responsible for crimes against humanity. In the result the State official, including a Head of State, is personally responsible for his crimes because customary international law is based on the appreciation that certain acts amounting to international crimes of individuals cannot be considered as legitimate performance of official functions of the State') and p. $5^{0}$ ('Though generally speaking international law does not directly impose obligations on individuals personally, it has become an accepted part of international law that individuals who commit international crimes are accountable to the world for them; and that as a matter of general customary international law it is no longer in doubt that a Head of State will personally be liable if there is sufficient evidence that he authorized or perpetrated those internationally recognized serious crimes alluded above'.

133 Ibid., p. 22: 'With respect to waiver of immunity and consent to surrender Article 98 [ICC Statute] provides the guidelines for cooperation. The Court can request for surrender or assistance only if it would not require the requested State to act inconsistently with its obligations under international law with respect to the State or diplomatic immunity of a person or property of a third State. In such a situation the Court must first obtain the cooperation or consent of the third State or sending State for the waiver of the immunity'. 
'although established as an independent court, the enforcement of [the ICC's] warrants [of arrest or transfer] remains with the States Parties, the broader international community and even in some cases with non-States Parties.'134 It added the following in regard to the question of the inter-action between Articles 27 and 98 of the Statute: ${ }^{135}$

The construction and import of this Article [98] and Article 27 aforesaid has been controversial. On the one hand, Article 27 declares that official capacity or status of the person sought to be arrested is irrelevant while on the other hand Article 98 seems to suggest that States must respect the State or diplomatic immunity of a person of another State, which only that other State can waive. The clear purpose of the Article is to explicit when a State is exempt from its obligations of cooperating with the ICC.

The provision is, no doubt designed to avoid competing international obligations that may be imposed on a State. It acknowledges that a State may have other international obligations that may abrogate its duty to cooperate with the ICC. However, cooperation to waive immunity can nonetheless be obtained from non-States Party. [...]

Accordingly, in the circumstances presented by this appeal Article 98(1) would preclude the ICC from proceeding with a request for arrest and surrender of President Al Bashir, if by doing so Kenya would be acting inconsistently with its obligations under international law with respect to the State or diplomatic immunity of President Al Bashir unless, of course Sudan was to waive the immunity of its President.

That view is entirely in line with what has been said above. The Court of Appeal of Nairobi then set out to consider how, under its own legal and constitutional order, the request of the ICC and President's Bashir immunities would interact. It came to the view that, under the legal system of Kenya, there was no exception to the obligation of the State to cooperate with a request for assistance of the ICC and that the immunities otherwise enjoyed by President Bashir provided no exception to that rule. ${ }^{136}$ This Judgment does not only support the

\footnotetext{
134 Ibid., pp. 30 et seq., in particular, p. 35 .

135 Ibid., p. 40.

${ }_{136}$ Kenya Appeals Decision, supra note 78, p. 46: 'Subject to the provisions of sections 62 and 115 aforesaid [of the International Crimes Act], by this enactment, Kenya as a State
} 
position advanced above. This judgment and that of the SCA also undermine any suggestion that domestic jurisdictions cannot be trusted to determine when and in what circumstances a State would be required to set aside the sovereign immunities of another State to fulfill its international obligations, including those it bears towards international tribunals. If anything, one must observe that those jurisdictions which failed to do so have thus far been tribunals from the Western hemisphere rather than from Africa. ${ }^{137}$

\section{Conclusions}

The era of absolute immunities for heads of States and other State officials suspected of involvement in the commission of international crimes is long gone. Such immunities have been eroded to a point where there is now a customary law exclusion of those as a defence to charges involving international crimes or as an objection to the jurisdiction of a tribunal that is otherwise competent to hear those charges. This limited customary law exclusion of immunities is triggered, not by the national or international character of the tribunal competent to hear the matter, but by the international character of the crime that underlies the charges. In thus excluding immunities as a defence and bar to jurisdiction, customary international law draws no distinction between official

acknowledged that the existence of any form of immunity attaching to the official capacity of any person whose arrest is sought by ICC would not be a ground for refusing to execute a request sought by the ICC for surrender or other assistance, including an arrest warrant, or for insisting that a person is ineligible for surrender, transfer, or removal to the ICC. We were not told that Kenya has consulted the ICC in terms of sections 62 and 115 [of the Act] on any form of conflict regarding its obligations to Sudan or any other State for the ICC to determine whether or not Article 98 of the Rome Statute applies to the request for execution of the arrest warrant and surrender'. Ibid., pp. 47-48: 'The choice was between cooperating with the ICC and remaining true to the Africa Union resolution not to cooperate with ICC. In view of the law that we have set out in this judgment, the former was the only tenable legal choice for Kenya; that is, to demonstrate its commitment to champion the fight on global impunity. By inviting President al Bashir to the inauguration of a new Constitution ... the Government of Kenya itself acted with impunity and joined States like Malawi, Djibouti, Chad, Uganda and the Democratic Republic of Congo ... against which the ICC has issued non-cooperation decisions and reported their failure to arrest President Al Bashir to the Security Council as well as the Assembly of States Parties'. Ibid., pp. 56-57, regarding Kenya's unqualified obligation to cooperate in this matter and obligation to 'disregard' President Al Bashir's immunity in order to execute the ICC's request for cooperation by arresting him.

See ibid. 
and private acts, nor does it differentiate between sitting and former State officials.

This limited customary law exclusion of immunities does not mean that immunities have become entirely irrelevant simply because an international crime is at stake. As the SCA noted in the Bashir case, there is as of yet no general, all-encompassing, international crimes exception to State immunities under customary international law. Instead, they remain applicable in principle outside the narrow framework of this exception to immunities as, for instance, where a request for judicial assistance clashes with the immunities of a third State if those have not been waived or otherwise validly set aside. Beyond that point and absent an express exclusion of immunities by reason of a treaty or Security Council resolution, general international law leaves it to the domestic laws of the State concerned (which includes whatever international law obligations it might have) to regulate the hierarchy of its competing international obligations. When looking into that particular question, the scA came to that very same conclusion. First, it determined that the ICC Statute did not provide for a ready-made solution to the challenge at hand. Article 27 reflects the customary law no-defence/no-jurisdictional bar exclusion but is irrelevant to resolving a question of immunities arising from a request for assistance.

As for Article 98 of the ICC Statute, it does not suggest that ICC obligations would necessarily prevail over any other international obligations of the requested State or would require that State to disregard its other international obligations to fulfill its obligations towards the ICc. Instead, it provides for two important safeguards enabling the ICC and the State concerned to arbitrate between various, potentially conflicting, international legal obligations. First, it provides for a blocking mechanism which sets a limit to the ability of the ICC to demand cooperation from a State where such cooperation would result in the requesting state violating the sovereign immunities of a third State or that of its officials. Secondly, it provides for a division of responsibilities where such a conflict arises. Namely, it is for the requested State to determine whether, according to its domestic legal order, compliance with a request from the ICC would violate other obligations under international law and, where such a conflict exists, it is for the ICC to try to resolve it (although the Court cannot, ultimately, request the State in question to act against what that State has determined to be its legal obligations under international law subject perhaps to the 'exceptional circumstances' exception mentioned above).

Being a State party to the ICC does not, therefore, provide general absolution from a duty to ensure that it acts in conformity with the immunities of a third State and to verify its own compliance with those immunities where the officials of that State are affected by the implementation of a request for 
assistance emanating from the ICC. Nor does the ICC Statute endow the ICC with the authority to order a State party to act in violation of other international obligations it owes to a third state.

The SCA's conclusion that neither customary international law nor the ICC Statute provided for a resolution of the issue at hand was therefore correct. It was right also for the SCA to ignore the theory of implicit waiver of immunities by the Security Council, a theory that finds little support in Resolution 1593 (2005) and is severely undermined as a theoretical proposition by evidence to the contrary. From the point of view of international law, the SCA's interpretation and its articulation of the relationship between international and domestic law was thus consistent with the framework that international law currently provides in relation to this issue.

States that have become parties to the ICc have indeed contracted out their ability to shield their officials on grounds of immunities and have renounced the ability to resist ICC requests for assistance pertaining to them on those same grounds. In contrast, neither the Statute, nor general international law, provides for a general international crime exception that would allow them to ignore the immunities of a third State. Where those come to clash with their obligations under the ICC Statute, and short of a Security Council resolution having explicitly set those immunities aside, the requested State will have to resolve the matter based on its own domestic legal order. This conclusion might frustrate those who would want to empower international criminal tribunals, but this seems to be the point that international law has reached thus far. 